\title{
ER $\propto$ Signaling in GHRH/Kiss1 Dual-Phenotype Neurons Plays Sex-Specific Roles in Growth and Puberty
}

\author{
${ }^{\circledR}$ David Garcia-Galiano, ${ }^{1}$ Alexandra L. Cara, ${ }^{1}$ Zachary Tata, ${ }^{2}$ Susan J. Allen, ${ }^{1}$ Martin G. Myers Jr, ${ }^{1,3}$ \\ Ernestina Schipani, ${ }^{2}$ and ${ }^{\circledR}$ Carol F. Elias ${ }^{1,4}$ \\ ${ }^{1}$ Department of Molecular and Integrative Physiology, ${ }^{2}$ Department of Orthopedic Surgery, Medicine, and Cell and Developmental Biology, \\ ${ }^{3}$ Department of Internal Medicine Division of Metabolism, Endocrinology and Diabetes, and ${ }^{4}$ Department of Gynecology and Obstetrics, University \\ of Michigan, Ann Arbor, Michigan 48109-5622
}

Gonadal steroids modulate growth hormone $(\mathrm{GH})$ secretion and the pubertal growth spurt via undefined central pathways. GH-releasing hormone (GHRH) neurons express estrogen receptor $\alpha(\mathrm{ER} \alpha)$ and androgen receptor (AR), suggesting changing levels of gonadal steroids during puberty directly modulate the somatotropic axis. We generated mice with deletion of ER $\alpha$ in GHRH cells $\left(\mathrm{GHRH}^{\mathrm{AER} \alpha}\right)$, which displayed reduced body length in both sexes. Timing of puberty onset was similar in both groups, but puberty completion was delayed in GHRH ${ }^{\Delta \mathrm{ER} \alpha}$ females. Lack of AR in GHRH cells (GHRH ${ }^{\Delta A R}$ mice) induced no changes in body length, but puberty completion was also delayed in females. Using a mouse model with two reporter genes, we observed that, while GHRH ${ }^{\text {tdTom }}$ neurons minimally colocalize with Kiss $1^{\text {hrGFP }}$ in prepubertal mice, $\sim 30 \%$ of GHRH neurons coexpressed both reporter genes in adult females, but not in males. Developmental analysis of Ghrh and Kiss1 expression suggested that a subpopulation of ER $\alpha$ neurons in the arcuate nucleus of female mice undergoes a shift in phenotype, from GHRH to Kiss1, during pubertal transition. Our findings demonstrate that direct actions of gonadal steroids in GHRH neurons modulate growth and puberty and indicate that GHRH/Kiss1 dual-phenotype neurons play a sex-specific role in the crosstalk between the somatotropic and gonadotropic axes during pubertal transition.

Key words: androgen receptor; bone; estrogen receptor $\alpha$; Kiss1; reproduction

Significance Statement

Late maturing adolescents usually show delayed growth and bone age. At puberty, gonadal steroids have stimulatory effects on the activation of growth and reproductive axes, but the existence of gonadal steroid-sensitive neuronal crosstalk remains undefined. Moreover, the neural basis for the sex differences observed in the clinical arena is unknown. Lack of ER $\alpha$ in GHRH neurons disrupts growth in both sexes and causes pubertal delay in females. Deletion of androgen receptor in GHRH neurons only delayed female puberty. In adult females, not males, a subset of GHRH neurons shift phenotype to start producing Kiss1. Thus, direct estrogen action in GHRH/Kiss1 dual-phenotype neurons modulates growth and puberty and may orchestrate the sex differences in endocrine function observed during pubertal transition.

\section{Introduction}

Proper timing of pubertal transition requires the interplay of endocrine, genetic, nutritional, and environmental factors for acquisition

Received Aug. 6, 2020; revised Sep. 7, 2020; accepted Oct. 25, 2020.

Author contributions: D.G.-G., E.S., and C.F.E. designed research; D.G.-G. performed research; D.G.-G., A.L.C., Z.T., S.J.A., and M.G.M. contributed unpublished reagents/analytic tools; D.G.-G. analyzed data; D.G.-G. wrote the first draft of the paper; D.G.-G. and C.F.E. edited the paper; D.G.-G. and C.F.E. wrote the paper.

The Animal Phenotyping Core was supported by P30 Grants DK020572 (MDRC) and DK089503 (MNORC). The Ligand Assay and Analysis Core-University of Virginia was supported by R24 Grant HD102061. This work was supported by National Institutes of Health R01 Grants HD069702 to C.F.E., DK056731 to M.G.M., and AR074079 to E.S. We thank Dr. Karel de Gendt and Dr Guido Verhoeven for generating and sharing the ARfloxed mouse model; and Dr. Rafael Pineda Reyes for technical assistance in image preparation.

The authors declare no competing financial interests.

Correspondence should be addressed to David Garcia-Galiano at bc2gagad@uco.es.

https://doi.org/10.1523/JNEUROSCI.2069-20.2020

Copyright $\odot 2020$ the authors of reproductive capacity and typical longitudinal growth (Sisk and Foster, 2004). Growth hormone (GH) release is classically regulated at the hypothalamic level by two neuronal populations: one that releases somatostatin with inhibitory action on GH secretion and another that synthesizes GH-releasing hormone (GHRH) with a stimulatory action mode. $\mathrm{GH}$ secretion is regulated peripherally by feedback mechanisms from hepatic insulin-like growth factor-1 (IGF-1) and gastric ghrelin signals (Steyn et al., 2016). Circulating GH concentration during development in humans and mice rises at birth, reduces in the prepubertal phase, and increases again at puberty when it induces the pubertal growth spurt (Rosenfeld, 2003). The pubertal increase in GH secretion is thought to be a direct response to gonadal maturation and increased circulating levels of gonadal steroids after a period of quiescence of the hypothalamo-pituitary-gonadal axis (Suter et al., 2000; Karpati et al., 2002; Kelly et al., 2014). Late maturing 
adolescents and juvenile mice often show reduced pubertal growth and slow linear growth progression likely because of delayed activation of the hypothalamo-pituitary-gonadal axis (Palmert and Dunkel, 2012; Garcia-Galiano et al., 2017).

$\mathrm{GH}$, in turn, also acts as an endocrine signal for the normal progression of sexual maturation. Women with $\mathrm{GH}$ deficiency or resistance display late timing of puberty onset, lack of sexual maturation, and infertility (de Boer et al., 1997). GH replacement for hypogonadotropic GH-deficient women accelerates puberty and stimulates fertility (Giampietro et al., 2009; Smuel et al., 2015). Studies have shown that GH acts at the gonadal level to stimulate sex steroid synthesis and follicle development by increasing ovarian sensitivity to gonadotropins (de Boer et al., 1999). However, whether gonadal steroids induce GH secretion during pubertal development by acting directly on GHRH neurons and whether these actions regulate the gonadal axis to facilitate pubertal maturation has not been demonstrated.

Changes in gonadal steroid levels modulate Ghrh expression and neuronal activity (Chowen et al., 1996; Gouty-Colomer et al., 2010). In rats, a subpopulation of hypothalamic GHRH neurons express estrogen receptor $\alpha(\mathrm{ER} \alpha)$, not $\mathrm{ER} \beta$ (Kamegai et al., 2001; Shimizu et al., 2005). Androgens, including the nonaromatizable dihydrotestosterone, also modulate hypothalamic Ghrh expression (Zeitler et al., 1990). Previous studies, however, have shown that GHRH neurons do not express detectable levels of androgen receptor (AR), suggesting that, if a direct effect exists, it is exerted via $\mathrm{ER} \alpha$ (Fodor et al., 2001).

In this study, we used the Cre-loxP system to assess whether direct actions of estrogens via $\mathrm{ER} \alpha$ or androgens via $\mathrm{AR}$ in GHRH neurons are necessary for typical growth, pubertal development, and reproductive physiology in mice. Using a dual-gene reporter mouse model, we further evaluated whether GHRH neurons constitute an integrative node in the crosstalk between the somatotropic and the gonadotropic axes in male and female mice.

\section{Materials and Methods}

Mouse models. The Ghrh-Cre (Rupp et al., 2018), Jax stock \#031096, the Kiss1-Cre (Cravo et al., 2011), Jax \#023426, the floxed Esr1 (Feng et al., 2007), the floxed $A r$ (De Gendt et al., 2004), the Kiss1-hrGFP (Cravo et al., 2013), Jax \#023425, and the reporters R26-LSL-tdTomato (Madisen et al., 2010), Jax \#007914, R26-LSL-eGFP (Jax \#004077) and R26-LSL-eGFP-L10a (Krashes et al., 2014) mice were housed in an Association for Assessment and Accreditation of Laboratory Animal Care-accredited animal facility at the University of Michigan, under controlled light cycle (12 h on/off) and temperature $\left(22 \pm 1^{\circ} \mathrm{C}\right)$ conditions. Mice were fed with a phytoestrogen-reduced diet (Teklad Diet 2916, Envigo), or a higher protein and fat phytoestrogen-reduced diet (Teklad Diet 2919, Envigo) when breeding, and had free access to water. A phytoestrogen-reduced diet was used to avoid the exogenous effect of estrogen on reproductive physiology. Day of birth was considered as postnatal day $0(\mathrm{P} 0)$. Mice were weaned at $21 \mathrm{~d}$ of age and group-housed with littermates of the same sex to a maximum of 5 per cage.

For deletion of ER $\alpha$ or AR signaling in GHRH-expressing neurons, the $\mathrm{GHRH}^{\mathrm{Cre}}$ mouse was crossed with a mouse carrying the loxP-modified $\operatorname{Esr} 1\left(\mathrm{ER} \alpha^{\mathrm{f} / \mathrm{l} \mathrm{l}}\right)$ or $A r\left(\mathrm{AR}^{\mathrm{f} / / \mathrm{fl}}\right)$ alleles. Our experimental mice were those heterozygous for GHRH-Cre allele $\left(\mathrm{GHRH}^{\mathrm{Cre} /+}\right)$ and homozygous for Esr1-loxP allele $\left(\mathrm{GHRH}^{\Delta \mathrm{ER} \alpha}\right)$ in males and females, or $A r$-loxP alleles $\left(\mathrm{GHRH}^{\Delta \mathrm{AR}}\right)$ in females, and hemizygous for $\mathrm{AR}^{\mathrm{f} / \mathrm{Y}}$ in males. Control groups were comprised of mice homozygous for the floxed alleles $\left(\mathrm{ER} \alpha^{\mathrm{fl} / \mathrm{ll}}, \mathrm{AR}^{\mathrm{f} / \mathrm{ll}}\right.$, or $\left.\mathrm{AR}^{\mathrm{f} / \mathrm{Y}}\right)$ and heterozygous for the Cre allele $\left(\mathrm{GHRH}^{\mathrm{Cre} /+}\right)$. In order to visualize GHRH-expressing neurons, we crossed the $\mathrm{GHRH}^{\mathrm{Cre} /+}$ with the eGFP-L10a (GHRH ${ }^{\mathrm{Cre} /+}$-eGFP) or tdTomato $\left(\mathrm{GHRH}^{\mathrm{tdTom}}\right)$ mice. In order to visualize Kiss1-expressing neurons, $\mathrm{Kiss}^{\mathrm{Cre}}$ mice were crossed with the eGFP (Kiss1 ${ }^{\text {Cre }}$-eGFP) mice (Frazao et al., 2013). Additionally, we crossed GHRH ${ }^{\text {tdTom }}$ with the Kiss ${ }^{\text {hrGFP }}$ mice to visualize both GHRHand Kiss1-expressing neurons (GHRH $\left.{ }^{\text {tdTom }}:: K_{i s s} 1^{\text {hrGFP }}\right)$. Mice were genotyped at weaning day and at the end of experiments. PCR amplification of the genomic floxed regions combined with the detection of the Cre and hrGFP transgenes and coding regions for reporter proteins was performed (Sigma Millipore, RED Extract-N-Amp Tissue PCR Kit \#XNAT). Kiss1 ${ }^{\text {Cre }}$-eGFP mice were kept on a C57BL6/J background, and $\mathrm{GHRH}^{\mathrm{Cre} /+}$-eGFP, GHRH ${ }^{\mathrm{Cre} /+}$-tdTomato, GHRH ${ }^{\Delta \mathrm{ER} \alpha}, \mathrm{GHRH}^{\Delta \mathrm{AR}}$, and GHRH ${ }^{\text {tdTom }}::$ Kiss $1^{\text {hrGFP }}$ strains were kept on a mixed C57BL6;129/SvJ background.

Experimental design. For phenotypic characterization of mouse models, metabolic and reproductive phenotypes were monitored. Experimental and control littermates were obtained from adjusted litter size (6-8 pups/litter at postnatal day 1) to avoid any metabolic effect during the lactational period (Caron et al., 2012; Garcia-Galiano et al., 2017). Assessment of the metabolic phenotype was evaluated by weekly body weight of male and female littermates. Body length was assessed at postnatal day 60 (P60) by snout-anus distance measurement in lightly anesthetized animals. Adult (10-week-old) $\mathrm{GHRH}^{\Delta \mathrm{ER} \alpha}(n=7)$ and control $(n=9)$ females were weighed and placed into an NMR-based analyzer (Minispec LF90II, Bruker Optics) for body fat and lean mass measurements in conscious animals.

Timing for puberty onset was monitored daily after weaning for vaginal opening (VO), a marker of puberty onset, and timing of the occurrence of first estrus, a marker for puberty completion. In males, timing of balano-preputial separation (BPS) was determined as a marker of puberty onset (Garcia-Galiano et al., 2017). Estrous cyclicity was assessed by daily collection of vaginal cytology in adult (starting at 10 weeks of age) virgin mice.

To assess changes in transcript levels, the arcuate nucleus (ARH) was dissected out, as described previously (Garcia-Galiano et al., 2017). Adult experimental and control males were deeply anesthetized with isoflurane (Fluriso, VetOne) and killed by decapitation. Trunk blood was quickly collected, and peripheral tissues were collected and immediately frozen on dry ice. Tissues were stored at $-80^{\circ} \mathrm{C}$ until RNA extraction was performed. Blood samples were allowed to clot for $45 \mathrm{~min}$ at room temperature and then centrifuged for $15 \mathrm{~min}$ at $2000 \times \mathrm{g}$, and the serum was collected and stored at $-20^{\circ} \mathrm{C}$. Additionally, brains and tibias from control and experimental mice were collected after perfusion with $10 \%$ neutral buffered formalin (Sigma Millipore), and brain coronal sections were processed for ISH or immunohistochemistry (IHC), as described below. For AR identification by IHC, GHRH ${ }^{\text {Cre/+}}$-eGFP males were single-housed for $5 \mathrm{~d}$ before perfusion to avoid dominance-subordination effects on androgen levels and AR expression in group-housed mice (Greenberg et al., 2014).

Bilateral ovariectomy (OVX) was performed on $\mathrm{ER} \alpha^{\mathrm{fl} / \mathrm{fl}}(n=10)$ and $\mathrm{GHRH}^{\Delta \mathrm{ER} \alpha}(n=9)$ mice under isoflurane anesthesia. A Silastic tube containing $1 \mu \mathrm{g}$ of $17 \beta$-estradiol ( $\mathrm{E}_{2}$, Sigma Millipore) suspended in sesame oil $\left(\mathrm{OVX}+\mathrm{E}_{2}\right)$ or oil $(\mathrm{OVX})$ was implanted under the skin at the time of the OVX. All animals were given carprofen as an analgesic $(5 \mathrm{mg} / \mathrm{kg})$ before and $12 \mathrm{~h}$ after and $24 \mathrm{~h}$ after surgery. Mice were killed after $4 \mathrm{~d}$ $\left(\mathrm{OVX}+\mathrm{E}_{2}\right)$ or $7 \mathrm{~d}(\mathrm{OVX})$. Trunk blood was collected and immediately diluted in assay buffer for detection of circulating luteinizing hormone (LH).

All experiments were conducted in accordance with the guidelines established by the National Institutes of Health Guide for the care and use of laboratory animals and Institutional Animal Care and Use Committee/Internal Animal Care and Use Committee (Protocols \#06792 and \#08712).

Hormone levels. After decapitation, whole blood was immediately diluted $1: 10$ in assay buffer $(0.2 \%$ BSA, $0.05 \%$ Tween 20 in $0.1 \mathrm{M}$ PBS) and stored at $-20^{\circ} \mathrm{C}$. Blood samples from diestrus, $\mathrm{OVX}$, and $\mathrm{OVX}+\mathrm{E}_{2}$ females of both groups $\left(\mathrm{ER} \alpha^{\mathrm{f} / \mathrm{fl}}\right.$ and $\mathrm{GHRH}^{\Delta \mathrm{ER} \alpha}$ ) were sent to the University of Virginia Ligand Assay and Analysis Core of the Center for Research in Reproduction (Charlottesville, Virginia) for measurements of the circulating LH levels. LH levels (in duplicate) were defined using a sensitive mouse and rat LH ELISA method (Steyn et al., 2013). The capture monoclonal antibody (anti-bovine LH- $\beta$ subunit, 518B7; RRID: AB_2665514) was provided by Janet Roser, University of California. The 
detection polyclonal antibody (rabbit LH antiserum; RRID:AB_2665533) was provided by the National Hormone and Peptide Program. HRP-conjugated polyclonal antibody (goat anti-rabbit) was purchased from DakoCytomation (D048701-2). Mouse LH reference prep (AFP5306A; National Hormone and Peptide Program) was used as the standard assay. Intra-assay coefficient of variation was $2.2 \%$. Interassay coefficients of variations were $1.3 \%$ (low QC, $0.2 \mathrm{ng} / \mathrm{ml}$ ), $2.1 \%$ (medium QC, $0.82 \mathrm{ng} / \mathrm{ml}$ ), and $3.9 \%$ (high QC, $2.58 \mathrm{ng} / \mathrm{ml}$ ). Functional sensitivity was $0.016 \mathrm{ng} / \mathrm{ml}$. For quantitative determination of mouse IGF-1 concentrations, a Quantikine ELISA immunoassay was implemented (\#MG100, R\&D Systems, RRID:AB_884569). The sensitivity of the mouse IGF-1 assay was $3.5 \mathrm{pg} / \mathrm{ml}$, (intra-assay CV 3.3\%-5.6\%; interassay CV 4.3\%-9.1\%).

Bone histology. Dissected hind limbs from perfused mice $(n=3$ or $4 /$ genotype) at P28 and P60 were immersed in 10\% neutral buffered formalin for $48 \mathrm{~h}$ at $4^{\circ} \mathrm{C}$ and then transferred to $70 \%$ ethanol for $24 \mathrm{~h}$ at $4^{\circ} \mathrm{C}$. Tibias were dissected and submerged in $20 \%$ EDTA for $14 \mathrm{~d}$ at $4^{\circ} \mathrm{C}$ with gentle agitation for decalcification (Mangiavini et al., 2016). EDTA solution was changed every third day for efficient mineral removal and then rinsed in PBS for $24 \mathrm{~h}$ at $4^{\circ} \mathrm{C}$. Specimens were transferred to $70 \%$ ethanol and then paraffin-embedded. Slices of bone at $7 \mu \mathrm{m}$ thickness were mounted and H\&E-stained for growth plate histology. Growth plate thickness from tibia proximal metaphysis in both genotypes was measured using ImageJ software (https://rsb.info.nih.gov/ij).

Immunofluorescence. Brains from $\mathrm{GHRH}^{\mathrm{Cre} /+}$-eGFP, Kiss $1^{\mathrm{Cre}}-\mathrm{eGFP}$,

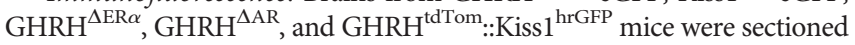
into $30 \mu \mathrm{m}$ coronal sections and stored in cryoprotectant for subsequent immunolabeling. Sections were incubated overnight at $4^{\circ} \mathrm{C}$ with primary chicken anti-GFP (1:10,000, AvesLabs, catalog \#GFP-1010; RRID:AB_ 2307313) and primary rabbit anti-ER $\alpha$ (1:5000, Millipore, catalog \# 06935; RRID:AB_310305), primary rabbit anti-AR (1:200, Abcam ab133273; RRID:AB_11156085), or primary sheep anti-TH (Millipore, catalog \#AB1542, 1:5000; RRID:AB_90755). Sections were rinsed and incubated with secondary donkey anti-chicken IgG conjugated with AlexaFluor-488 (Invitrogen) and anti-rabbit IgG conjugated with AlexaFluor-594 for $1.5 \mathrm{~h}$. For AR immunodetection, after primary antibody incubation, sections were previously incubated in $0.6 \% \mathrm{H}_{2} \mathrm{O}_{2}$ and in secondary biotinconjugated donkey anti-rabbit IgG (1:1000, Jackson ImmunoResearch Laboratories). Sections were incubated in $\mathrm{ABC}$ solution (1:1000, Vector Labs) and in biotin tyramide solution for 10 min (1:250, PerkinElmer), then incubated with streptavidin conjugated with AlexaFluor-594 (1:1000, Invitrogen), as referenced (Low et al., 2017). Sections then were mounted on gelatin-precoated slides and coverslipped with ProLong gold antifade mountant medium (Invitrogen). The tdTomato or the hrGFP fluorescence did not require additional immunostaining.

IHC. Free-floating sections from adult $\mathrm{GHRH}^{\mathrm{Cre} /+}$-eGFP mice $(n=3)$ were rinsed in PBS and followed by pretreatment with a solution of $1 \% \mathrm{H}_{2} \mathrm{O}_{2}$ for $30 \mathrm{~min}$ to quench the endogenous peroxidases. Tissue was blocked in $3 \% \mathrm{BSA}$, then incubated with a primary chicken anti-GFP antibody $(1: 10,000)$ overnight at $4^{\circ} \mathrm{C}$. Sections were incubated for $1 \mathrm{~h}$ in donkey biotinylated anti-chicken IgG (1:1000, Jackson ImmunoResearch Laboratories), followed by $1 \mathrm{~h}$ incubation with avidin-biotin complex (1:500, Vector Labs). The detection reaction was performed using $0.05 \%$ $\mathrm{DAB}$ and $0.01 \%$ hydrogen peroxide. Sections were mounted onto gelatincoated slides and coverslipped with DPX medium (Electron Microscopy Sciences).

ISH. Single ISH was performed to determine the hypothalamic distribution of Ghrh mRNA expression in $\mathrm{ER}^{\mathrm{fl} / \mathrm{fl}}(n=3)$ and $\mathrm{GHRH}^{\Delta \mathrm{ER} \alpha}$ $(n=2)$ in adult males. Briefly, a series of brain sections were mounted onto SuperFrost plus slides (Thermo Fisher Scientific), fixed in 10\% neutral buffered formalin for $20 \mathrm{~min}$, and cleared with xylene for $15 \mathrm{~min}$. Slides were boiled in sodium citrate buffer, $\mathrm{pH}$ 6.0, for $10 \mathrm{~min}$. The Ghrh DNA template was generated from mouse hypothalamic RNA by PCR amplification, as previously described (Wasinski et al., 2020). The antisense radiolabeled ${ }^{33} \mathrm{P}-G h r h$ riboprobe was generated by in vitro transcription using a T7 RNA polymerase (Promega). ${ }^{33} \mathrm{P}$-labeled riboprobe was diluted in hybridization solution (50\% formamide, $10 \mathrm{~mm}$ Tris- $\mathrm{HCl}, \mathrm{pH}$ 8.0, $5 \mathrm{mg}$ tRNA, $10 \mathrm{~mm}$ dithiothreitol/DTT, $10 \%$ dextran sulfate, $0.3 \mathrm{M}$ $\mathrm{NaCl}, 1 \mathrm{~mm}$ EDTA, and $1 \times$ Denhardt's solution), and brain slices were hybridized overnight at $57^{\circ} \mathrm{C}$. Posthybridization slides were incubated in
0.002\% RNase A followed by stringency washes in SSC (sodium chloridesodium citrate buffer). Sections were then dipped in NTB autoradiographic emulsion (Kodak) and stored in light-protected slide boxes at $4^{\circ} \mathrm{C}$ for 2 weeks. Signal was developed with developer and fixer (Carestream), and the slides were coverslipped with DPX (Electron Microscopy Sciences) mounting medium.

Dual-label ISH and IHC. Dual-label ISH and IHC were performed to determine the localization of Ghrh mRNA in GHRH ${ }^{\text {tdTom }}$ neurons during development, as previously described (Garcia-Galiano et al., 2017). Briefly, free-floating sections from prepubertal (P21), peripubertal (P28-P36), and adult (P60) females ( $n=3 /$ age) were treated with $0.1 \%$ sodium borohydride for $15 \mathrm{~min}$ and $10 \mathrm{~min}$ with $0.25 \%$ acetic anhydride in DEPC-treated $0.1 \mathrm{~m}$ triethanolamine (TEA, $\mathrm{pH}$ 8.0). Sections were incubated overnight at $50^{\circ} \mathrm{C}$ in the hybridization solution containing the ${ }^{33} \mathrm{P}-G h r h$ riboprobe. Subsequently, sections were treated with RNase A for $30 \mathrm{~min}$ and submitted to stringency washes in SSC (sodium chloridesodium citrate buffer). Sections were blocked (3\% BSA in PBS-Triton) and then incubated with anti-dsRed antibody (1:5000, Clontech \#632496; RRID:AB_10013483) overnight at $4^{\circ} \mathrm{C}$. Sections were incubated for $1.5 \mathrm{~h}$ in a donkey anti-rabbit AlexaFluor-594 antibody and mounted onto SuperFrost plus slides. After overnight air-drying, slides were dehydrated in increasing concentrations of ethanol and dipped in NTB-2 autoradiographic emulsion (Kodak), dried, and stored in lightprotected boxes at $4^{\circ} \mathrm{C}$ for $4 \mathrm{~d}$. Finally, slides were developed with D-19 developer (Kodak), dehydrated in graded ethanol, cleared in xylenes, and coverslipped with DPX mounting medium.

FISH. FISH for Ghrh and Kiss1 was performed using the RNAscope fluorescent multiplex detection Kit (Advanced Cell Diagnostics). Brains from diestrus and OVX ( $n=3$ /group) mice were collected and immediately frozen on dry ice, then cut into 5 series of $16 \mu \mathrm{m}$ sections on a cryostat at $-20^{\circ} \mathrm{C}$, and mounted onto Superfrost Plus slides. Slides were dried at $60^{\circ} \mathrm{C}$ and fixed in $10 \%$ buffered formalin for $2 \mathrm{~h}$ at $4^{\circ} \mathrm{C}$, then dehydrated in increasing concentrations of ethanol, cleared in xylenes, and rehydrated in decreasing concentrations of ethanol. Slides were boiled for $10 \mathrm{~min}$ in sodium citrate buffer and incubated for $10 \mathrm{~min}$ in $0.03 \%$ SDS. Slides were dried at room temperature with a hydrophobic barrier around the sections. Endogenous peroxidase activity was blocked with $\mathrm{H}_{2} \mathrm{O}_{2}$ for 10 min and RNAscope protease III was then applied on slides and incubated for $30 \mathrm{~min}$ at $40^{\circ} \mathrm{C}$. Hybridization was performed by applying target probes to sections for $2 \mathrm{~h}$ at $40^{\circ} \mathrm{C}$. Then, the amplification and detection of each probe were performed according to the protocol for RNAscope Multiplex Fluorescent v2 assay. Finally, slides were counterstained with DAPI and coverslipped with ProLong Gold (Thermo Fisher Scientific) antifade mounting medium.

$q P C R$. Arcuate punches from adult $\mathrm{ER} \alpha \alpha^{\mathrm{t} / \mathrm{ll}}(n=6)$ and $\mathrm{GHRH}^{\Delta \mathrm{ER} \alpha}$ $(n=5)$ males were homogenized in Qiazol reagent (QIAGEN), and total RNA was isolated using an RNA extraction kit (miRNeasy, QIAGEN). The mRNA from liver samples was extracted with TRIzol reagent (Invitrogen). Complementary DNA was synthesized using a SuperScriptII reverse transcriptase and random primers (Invitrogen) according to the manufacturer's protocol. Gene expression analyses were performed by qPCR using a CFX-384 Bio-Rad Real-Time PCR detection system in a SYBR Green reaction. Changes in the expression of growth axis-related genes were evaluated using specific oligo primers: Ghrh (forward: CAACTGTACCCTGTTACTTC; reverse: TTTTTGCAGATGAGAATG GG), Sst (forward: TCTGCATCGTCCTGGCTTT; reverse: CTTGGCCA GTTCCTGTTTCC), $G h r$ (forward: GATTTTACCCCAGTCCCAGTTC; reverse: GACCCTTCAGTCTTCTCATCCACA), and Igf1 (forward: GA CAAACAAGAAAACGAAGC; reverse: ATTTGGTAGGTGTTTTCGA TG). Gapdh (forward: GCTCATGACCACAGTCCATGC; reverse: GTT GGGATAGGGCCTCTCTTG) expression was used as a housekeeping gene. Primers were purchased from Sigma Millipore. The mRNA expression in mutant versus control mice was determined by a comparative cycle threshold $\left(C_{t}\right)$ method, and relative gene copy number was calculated as $2^{-\Delta \Delta \mathrm{Ct}}$ and presented as the percentage of the relative mRNA expression of the control group.

Photomicrograph production and quantification of $m R N A$ and protein expression. Photomicrographs were acquired using an Axio Imager M2 (Carl Zeiss) and a Nikon inverted A1 confocal microscope. The 

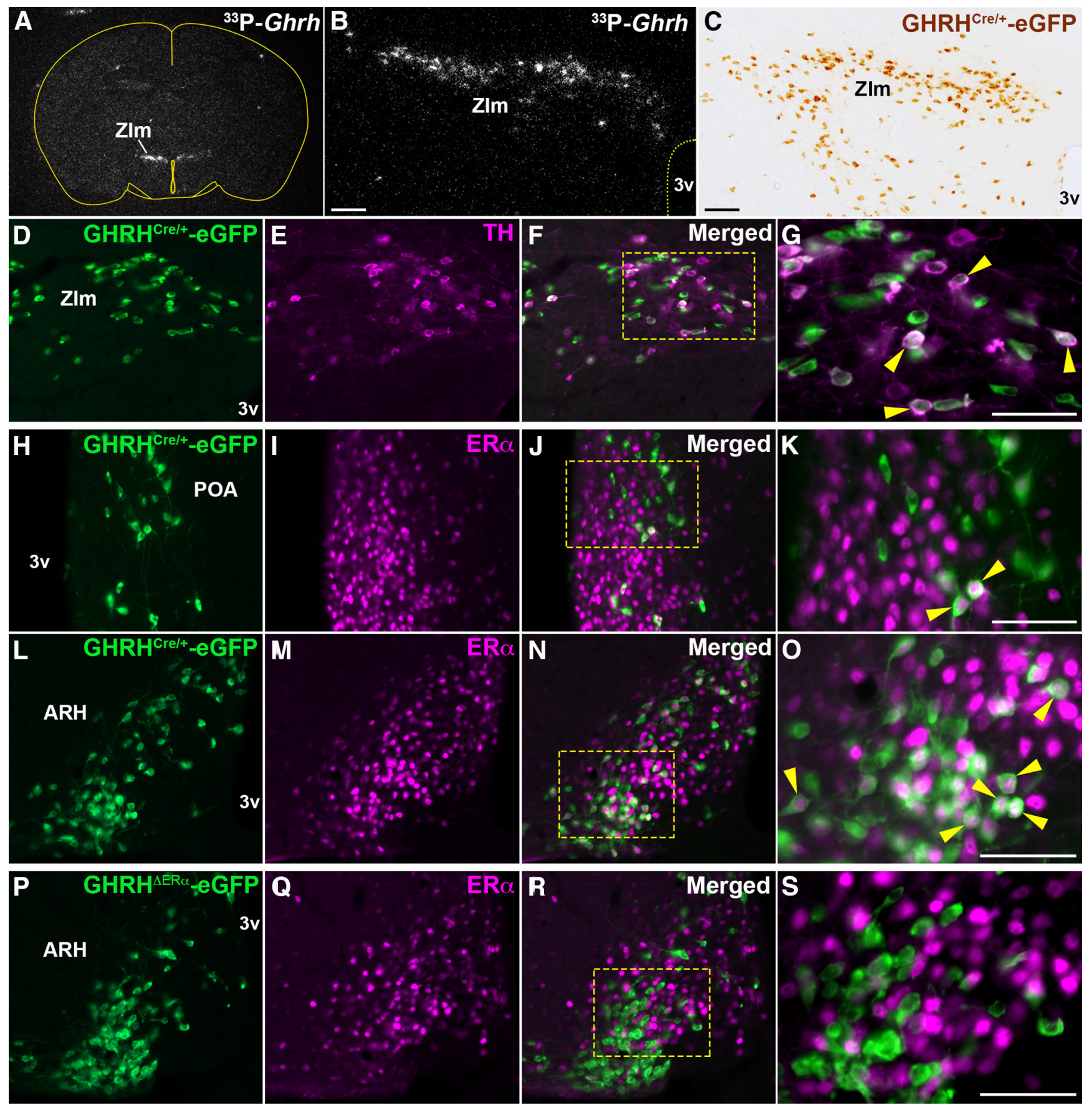

Figure 1. Distribution of hypothalamic GHRH-eGFP neurons expressing TH or ER $\alpha$ immunoreactivity (ir). $\boldsymbol{A}, \boldsymbol{B}$, Representative darkfield micrographs showing the distribution of Ghrh mRNA labeled with ${ }^{33} \mathrm{P}$-radioisotope in the ZIm by ISH. C, Brightfield micrograph showing the distribution of GHRH ${ }^{\text {(re/ }+}$-eGFP-ir (brown) in Zlm. D-G, Fluorescent micrographs showing colocalization (arrowhead) of TH- (magenta) and GHRH-eGFP-ir (green) in ZIm (28.24 $\pm 4.58 \%$ of eGFP ${ }^{+}$cells). Higher-magnification micrograph for the selected area in $\boldsymbol{F}$ is shown in $\mathbf{G}$. $\boldsymbol{H}-\mathbf{0}$, Fluorescent micrographs showing colocalization (arrowhead) of ER $\alpha$ - (magenta) in GHRH ${ }^{\text {Cre/ }}$-eGFP-ir positive cells in the medial POA $(18.21 \pm 6.86 \% ; \boldsymbol{H}-\boldsymbol{K})$ and ARH $(44.15 \pm 4.07 \% ; \mathbf{L}-0)$. Higher-magnification micrographs of $\boldsymbol{J}$ and $\boldsymbol{N}$ are shown in $\boldsymbol{K}$ and $\boldsymbol{O}$, respectively. $\boldsymbol{P}$-S, Fluorescent micrographs showing ER $\alpha$ - and GHRH ${ }^{\text {Cre/+ }}$-eGFP-ir neurons in the ARH of an adult GHRH ${ }^{\Delta E R \alpha}$ female mouse (4.82 $\pm 2.35 \%$ of eGFP ${ }^{+}$). A higher-magnification micrograph for the selected area in $\boldsymbol{R}$ is shown in $\mathbf{S}$. $3 \mathrm{v}$, Third ventricle. Scale bars: $\boldsymbol{B}, \boldsymbol{C}, 100 \mu \mathrm{m} ; \boldsymbol{G}, \boldsymbol{K}, \mathbf{O}, \mathbf{S}, 50 \mu \mathrm{m}$.

number of $\mathrm{ARH} \mathrm{GHRH}^{\mathrm{Cre} /+}$-eGFP ${ }^{+}$neurons was determined in one side of ARH using Image 2.0 Cell Counter software. $\mathrm{GFP}^{+}$cells were counted at three different levels of ARH, using the Allen Brain Atlas (https://mouse.brain-map.org/static/atlas) for neuroanatomical reference (rostral [image 68], tuberal [image 73], and caudal [image 77] levels) in GHRH-eGFP males and females at P21 and P60. The number of ARH Kiss $1^{\text {Cre }}$-eGFP neurons was determined by counting the total $\mathrm{eGFP}^{+}$cells at tuberal and caudal arcuate levels in prepubertal (P15) and diestrus Kiss $1^{\mathrm{Cre}}$-eGFP females, and in prepubertal (P23) and adult Kiss $1^{\text {Cre }}$-eGFP males. To estimate the proportion of ARH Kiss ${ }^{\text {hrGFP }}$ cells colabeled with $\mathrm{GHRH}^{\text {tdTom }}$, hrGFP ${ }^{+}$and double-labeled cells were counted at three different levels (from rostral to caudal) of ARH. The proportion of ARH GHRH ${ }^{\text {tdTom }}::$ Kiss $1^{\text {hrGFP }}$ neurons was estimated in prepubertal (P21) and adult (P56) GHRH ${ }^{\mathrm{Cre} /+}$ and $\mathrm{GHRH}^{\mathrm{ER} \alpha}$ females. ARH GHRH ${ }^{\text {tdTom }}:: K_{i s s} 1^{\text {hrGFP }}$ coexpression was also estimated in males at different ages (P21, P36, and P84). For quantification of Ghrh mRNA levels in different groups, all darkfield images were acquired with the same light intensity and exposure time, and images were quantified using ImageJ. Image-editing software (Adobe Photoshop 2020) was used to integrate graphs and digital images into figures. 

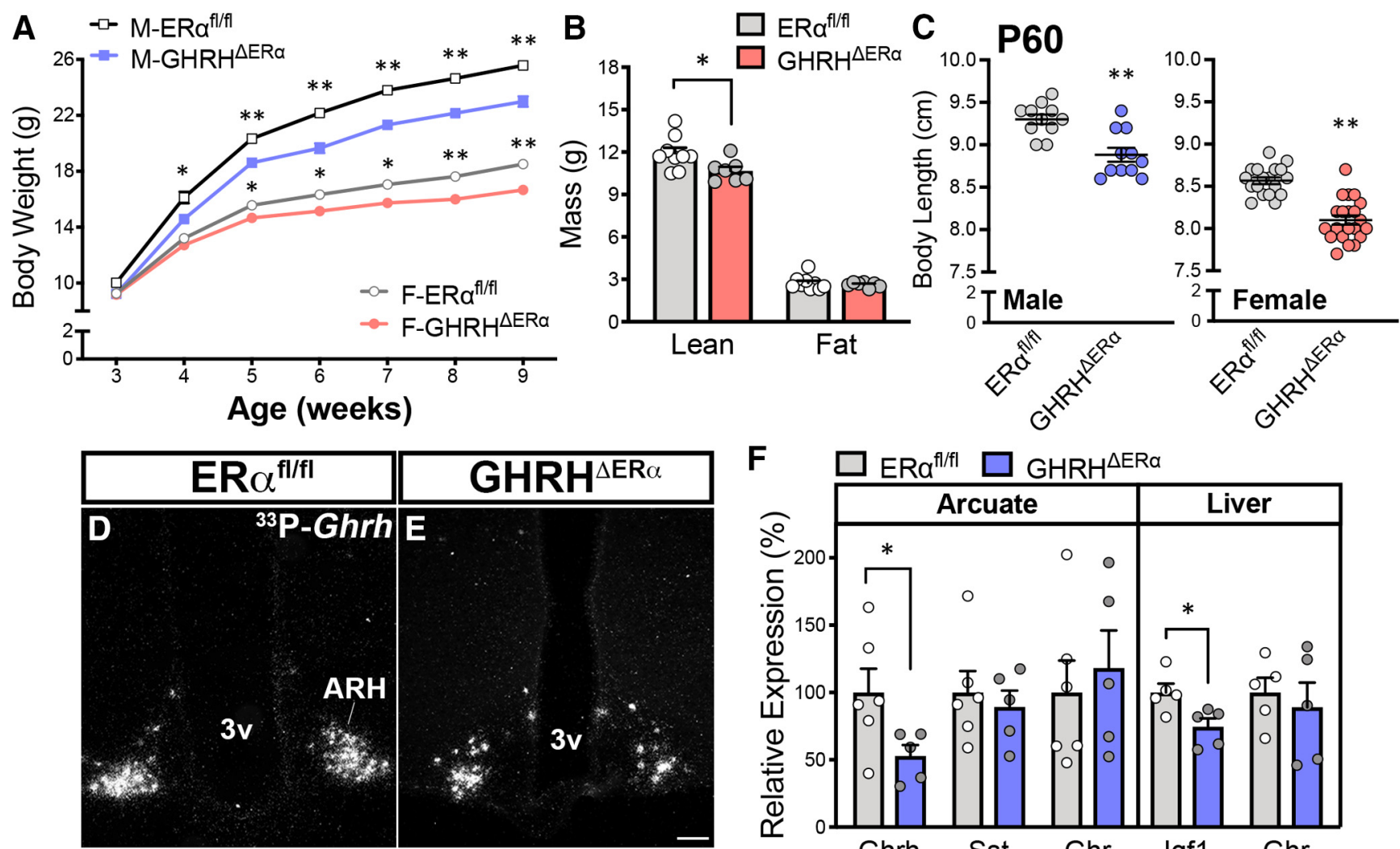

F $\square \mathrm{ERa}^{\mathrm{fl} / \mathrm{fl}} \square \mathrm{GHRH}^{\Delta \mathrm{ERa}}$
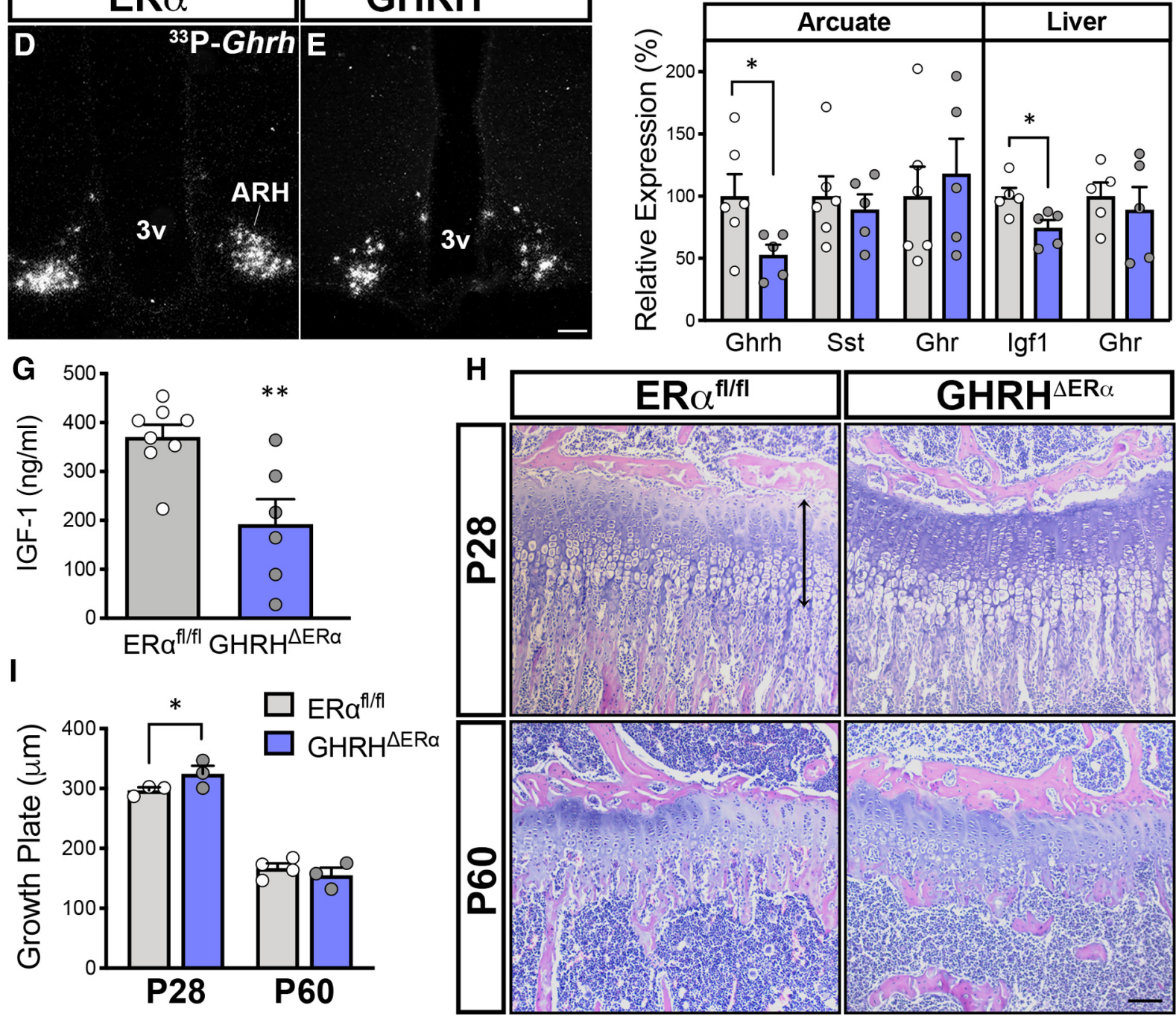

Figure 2. Mice with deletion of ER $\alpha$ in GHRH cells have altered growth axis. $\boldsymbol{A}$, Reduced body weight of GHRH ${ }^{\Delta \mathrm{ER} \alpha}$ males (M; $n=14 /$ genotype) and females (F; $n=24-26 /$ genotype) versus $E R \alpha^{\text {fl/ffl }}$ males $\left(F_{(1,26)}=37.79, p<0.0001\right)$ and females $\left(F_{(1,48)}=30.97, p<0.0001\right)$ by two-way repeated-measures ANOVA with Sidak's multiple comparisons. $\boldsymbol{B}$, Altered lean mass in adult GHRH ${ }^{\Delta E R \alpha}(n=7)$ versus ER $\alpha^{\text {fl/fl }}$ females $\left(n=9 ; t_{(14)}=2.75, p=0.017\right)$. No differences in fat mass were observed. $C$, Reduced body length at P60 in $\mathrm{GHRH}^{\Delta \mathrm{ER} \alpha}$ males $(n=11)$ and females $(n=21)$ versus ER $\alpha^{\mathrm{fl} / \mathrm{fl}}$ males $\left(n=11 ; t_{(20)}=4.19, p<0.0005\right)$ and females $\left(n=18 ; t_{(37)}=6.78, p<0.0001\right)$. D, E, Representative darkfield micrographs showing Ghrh mRNA (hybridization signal) in the ARH of ER $\alpha^{\mathrm{fl} / \mathrm{fl}}$ and GHRH ${ }^{\Delta E R \alpha}$ males. $\boldsymbol{F}$, Relative mRNA expression levels for Ghrh, Sst, and Ghr genes in ARH punches

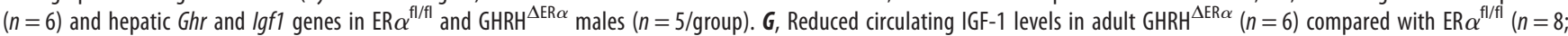
$\left.t_{(12)}=3.41, p=0.005\right)$ males. $\boldsymbol{H}$, Representative brightfield micrographs of the tibial growth plate at proximal metaphysis of ER $\alpha^{\mathrm{fl} / \mathrm{fl}}$ and $\mathrm{GHRH}{ }^{\Delta E R \alpha}$ mice at P28 ( $\left.n=3 / \mathrm{group}\right)$ and P60 ( $n=3$ or 4/group) stained with H\&E. $I$, Bar graphs represent size of the growth plate in pubertal $\left(P 28 ; t_{(12)}=2.56, p=0.025\right)$ and adult $(\mathrm{P} 60)$ mice. $* p<0.05 ; * * p<0.01$; unpaired two-tailed Student's $t$ test. 3v, Third ventricle. Scale bar, $100 \mu \mathrm{m}$. 
Statistical analyses. Data are expressed as mean \pm SEM. The unpaired two-tailed Student parametric and nonparametric $t$ tests were used for comparison between two groups (e.g., $\mathrm{ER} \alpha^{\mathrm{fl} / \mathrm{fl}}$ vs $\mathrm{GHRH}^{\Delta \mathrm{ER} \alpha}$ mice). When more than two experimental groups were present in the analysis, one-way ANOVA followed by Tukey's post hoc comparison test was used. For multiple analysis, two-way ANOVA followed by Tukey's post hoc test was used, unless otherwise noted. A description of the statistical method used in each analysis is noted in the figure legends. Statistical analysis was performed using GraphPad Prism version 8 software. A $p$ value of $<0.05$ was considered significant in all analyses.

\section{Results}

Distribution of Ghrh and GHRH-eGFP expression in the hypothalamus

Because gonadal steroid receptors are widely expressed in the CNS (Merchenthaler et al., 2004; Brock et al., 2015), we performed a systematic evaluation of Cre expression in $\mathrm{GHRH}^{\mathrm{Cre} /+}$ mice using the Cre-induced eGFP-L10a reporter gene (Krashes et al., 2014). As expected, the hypothalamic distribution of $\mathrm{eGFP}^{+}$cells was similar to that of Ghrh mRNA (Rupp et al., 2018; Wasinski et al., 2020). Prominent expression of Ghrh and $\mathrm{eGFP}^{+}$was observed in the medial zona incerta (ZIm) (Fig. 1A-C), dorsomedial nucleus of the hypothalamus, and in the dorsomedial and ventrolateral aspects of the ARH. A moderate expression of the reporter gene was also found in the preoptic area (POA), in the paraventricular nucleus of the hypothalamus, and in the lateral hypothalamic area.

The ZIm and ARH house the A13 and A12 dopaminergic groups, respectively (Hokfelt et al., 1976), both associated with reproductive physiology (MacKenzie et al., 1984; Pasqualini et al., 1988; Sanghera et al., 1991a). Previous studies have shown colocalization of $\mathrm{TH}$, the rate-limiting enzyme for catecholamine synthesis, with GHRH immunoreactivity (ir) in rats and in GHRH-eGFP ${ }^{+}$neurons of mice (Meister et al., 1986; Phelps et al., 2003; Bouyer et al., 2007). Using the GHRH ${ }^{\mathrm{Cre} /+}$-eGFP mouse, we found that coexpression of eGFP- and TH-ir is mainly observed in the ZIm ( $\sim 30 \%$ of $\mathrm{GHRH}^{\mathrm{Cre} /+}$-eGFP ${ }^{+}$neurons; Fig. $\left.1 D-G\right)$.

\section{Mice with deletion of ER $\alpha$ in GHRH cells have altered growth} axis

The GHRH-eGFP ${ }^{+}$neurons that coexpress ER $\alpha$ were restricted to the POA, ZIm, and ARH. We found that $~ 20 \%$ of POA, $30 \%$ of ZIm, and $45 \%$ of ARH GHRH-eGFP cells coexpress ER $\alpha$ in adult females (Fig. $1 H-O$ ). In adult males, $\sim 15 \%$ of POA and ZIm, and $48 \%$ of ARH GHRH-eGFP cells coexpress $\mathrm{ER} \alpha$.

The mouse model with specific deletion of ER $\alpha$ in GHRH cells $\left(\mathrm{GHRH}^{\Delta \mathrm{ER} \alpha}\right.$ mice) showed a minimal colocalization of $\mathrm{ER} \alpha$ in GHRH-eGFP ${ }^{+}$neurons of the POA, ZIm, and ARH (Fig. $1 P-S$ ), indicating that the Cre-LoxP procedure was successful.
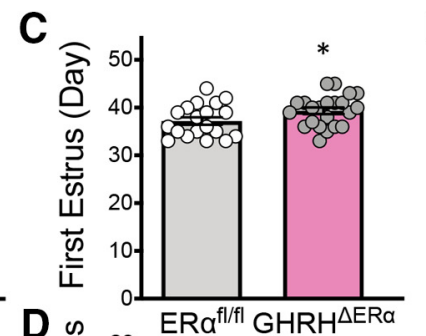

E
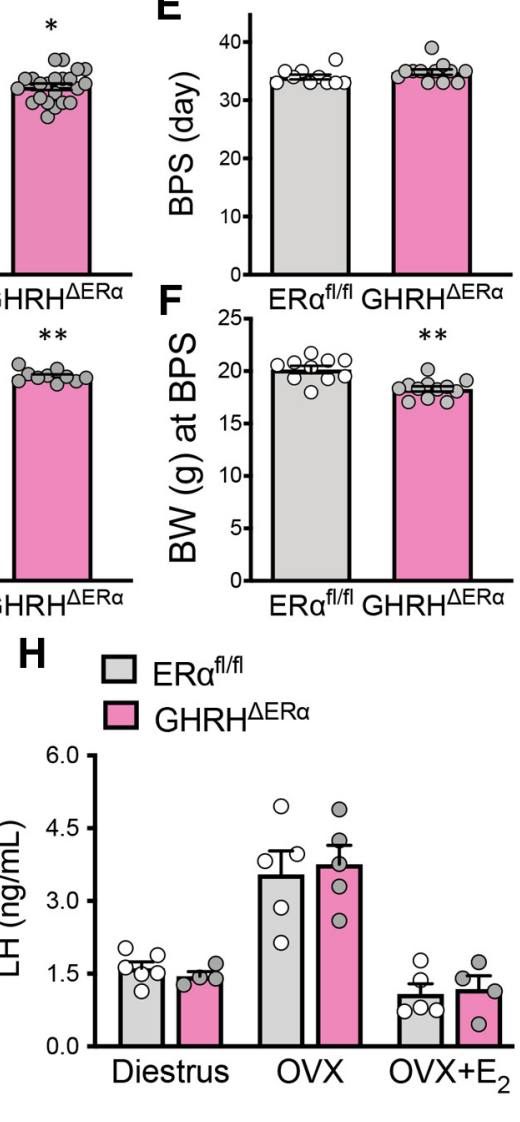

Figure 3. Mice with deletion of $E R \alpha$ in GHRH cells have delayed pubertal completion. $\boldsymbol{A}-\boldsymbol{F}$, Bar graphs represent $(\boldsymbol{A})$ day of V0 $\left(t_{(39)}=1.88, p=0.067\right),(\boldsymbol{B})$ body weight at day of V0 $\left(t_{(36)}=0.39, p=0.69\right),(\boldsymbol{C})$ day of first estrus $\left(t_{(39)}=2.08\right.$, $p=0.044),(\boldsymbol{D})$ corporal weight at day of first estrus $\left(t_{(16)}=3.59, p=0.003\right),(\boldsymbol{E})$ day of BPS $\left(t_{(20)}=1.29, p=0.21\right)$, and $(\boldsymbol{F})$

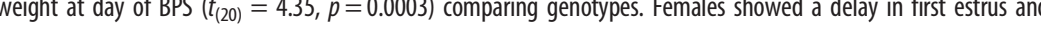
$\left(\mathrm{OVX} ; t_{(8)}=0.33, p=0.75\right)$, and OVX supplemented with $17 \beta$-estradiol $\left(\mathrm{E}_{2} ; t_{(7)}=0.30, p=0.77\right)$ mice comparing genotypes. E, Estrus; $\mathrm{P}$, proestrus; $\mathrm{M}$, metestrus; $\mathrm{D}$, diestrus. $* p<0.05 ; * * p<0.01$; unpaired two-tailed Student's $t$ test.

Phenotypically, GHRH ${ }^{\Delta \mathrm{ER} \alpha}$ males and females showed reduced body weight compared with littermate controls (Fig. $2 A)$. In $\mathrm{GHRH}^{\Delta \mathrm{ER} \alpha}$ males, a difference in body weight was observed after 4 weeks of age, and after 5 weeks of age in $\mathrm{GHRH}^{\Delta \mathrm{ER} \alpha}$ females. Reduced body weight in $\mathrm{GHRH}^{\Delta \mathrm{ER} \alpha}$ females, but not in males, was associated with a significant reduction in lean mass, but no changes in fat mass (Fig. $2 B$ ). $\mathrm{GHRH}^{\Delta \mathrm{ER} \alpha}$ males and females had reduced body length compared with littermate controls at P60 (Fig. 2C).

Because of the effects on somatic growth, we assessed changes in the expression of associated genes in adult (P60) male mice. A reduction in ARH Ghrh expression was detected in $\mathrm{GHRH}^{\Delta \mathrm{ER} \alpha}$ mice by ISH and qPCR from micro-punches (Fig. 2D-F). No changes in ARH Sst (somatostatin) or Ghr (GH receptor) expression were observed between genotypes. Similar hepatic Ghr expression was detected in both genotypes, but reduced hepatic Igf1 expression and circulating IGF-1 levels were observed in GHRH $^{\Delta \mathrm{ER} \alpha}$ mice (Fig. 2G).

The GHRH ${ }^{\Delta \mathrm{ER} \alpha}$ mice displayed an increase in tibia growth plate thickness at P28 (Fig. $2 H$ ), with higher columnar chondrocyte proliferation compared with $\mathrm{ER} \alpha^{\mathrm{fl} / \mathrm{fl}}$ control males, suggesting a delay in bone age in pubertal GHRH ${ }^{\Delta \mathrm{ER} \alpha}$ mutant mice (Fig. 2I). No $\mathrm{GHRH}_{-} \mathrm{eGFP}^{+}$cells were detected in the growth plate, and no difference in growth plate thickness was observed in adult mice. 

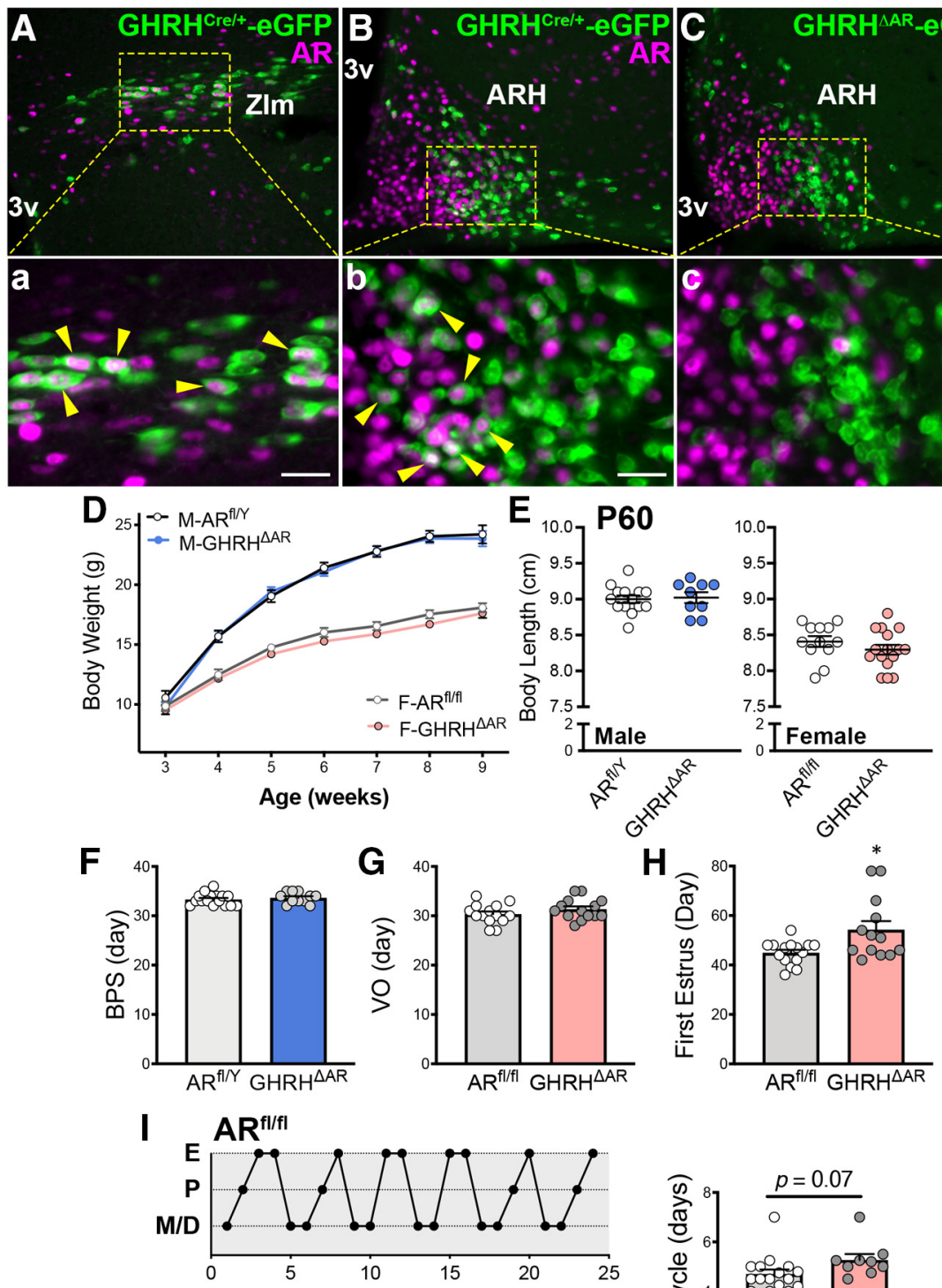

GHRH $^{\triangle A R}$
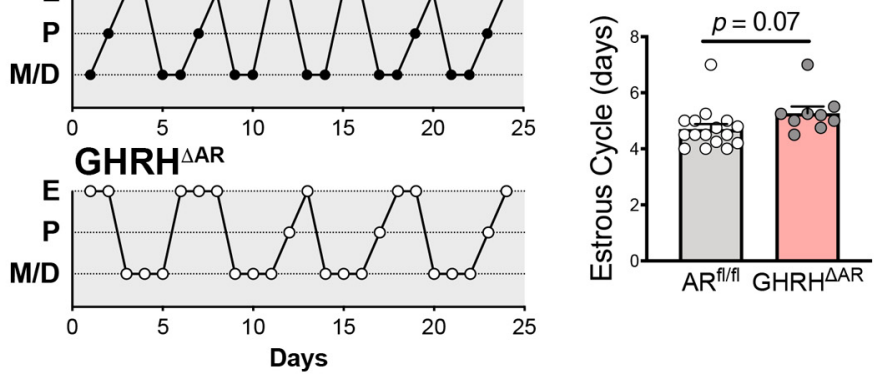

Figure 4. Mice with deletion of AR in GHRH cells have normal growth, but females show delayed pubertal completion. $\boldsymbol{A}$ $\boldsymbol{B}$, Representative fluorescent micrographs showing colocalization (arrowhead) of AR- (magenta) and GHRH ${ }^{\text {Cre/+ }}$-eGFP (green) immunoreactivity (-ir) in the $\mathrm{ZIm}\left(28.28 \pm 9.93 \%\right.$ of $\mathrm{eGFP}^{+}$cells; $\left.\boldsymbol{A}\right)$ and in the ARH $(22.98 \pm 3.30 \%$; $\boldsymbol{B})$ in males. $\boldsymbol{C}$, Fluorescent micrograph showing AR-ir and $\mathrm{GHRH}^{\mathrm{Cre} /+}$-eGFP-ir in the ARH of $\mathrm{GHRH}^{\triangle A R}$ mice. Note lack of colocalization $(0.71 \pm 0.81 \%)$, indicating successful deletion of AR in GHRH neurons. Higher-magnification micrographs of the selected area

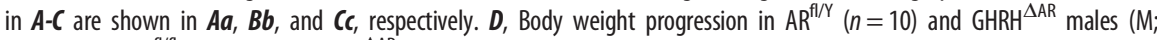
$n=16)$; and $\operatorname{AR}^{\mathrm{fl} / \mathrm{fl}}(n=17)$ and $\mathrm{GHRH}^{\Delta \mathrm{AR}}$ females $(\mathrm{F} ; n=21)$, by two-way repeated-measures ANOVA with Sidak's multiple comparisons. $\boldsymbol{E}$, Body length at $\mathrm{P} 60$ in $\mathrm{GHRH}^{\Delta A R}(n=9)$ versus $\mathrm{AR}^{\mathrm{fl} / \mathrm{Y}}(n=14)$ males and $\mathrm{GHRH}^{\Delta A R}(n=16)$ versus $A R^{\mathrm{fl} / \mathrm{fl}}$ $(n=12)$ females. $\boldsymbol{F}$, Day of BPS. $\boldsymbol{G}$, Day of V0. $\boldsymbol{H}$, First estrus. Note delay in pubertal completion (first estrus) in GHRH ${ }^{\triangle A R}$ $(n=13)$ compared with controls $\left(n=15 ; t_{(15)}=2.55, p=0.022\right)$. I, Representative estrous cycles of 2 mice from each genotype. No differences in estrous cycle were detected between genotypes $\left(t_{(23)}=1.89, p=0.071\right) . * p<0.05$ (unpaired twotailed Student's $t$ test with Welch's correction). Each point represents 1 individual mouse. 3v, Third ventricle. Scale bar, $50 \mu \mathrm{m}$.

Mice with deletion of ER $\alpha$ in GHRH cells have delayed pubertal completion

Puberty onset (day of VO) and body weight at the day of VO were not altered in $\mathrm{GHRH}^{\Delta \mathrm{ER} \alpha}$ mice with respect to controls (Fig. $3 A, B$ ). In contrast, puberty completion was delayed and body weight at the day of the first estrus was reduced in $\mathrm{GHRH}^{\Delta \mathrm{ER} \alpha}$ females (Fig. $3 C, D)$. In males, no differences in age of puberty onset, revealed by the day of BPS, were detected comparing genotypes, although $\mathrm{GHRH}^{\Delta \mathrm{ER} \alpha}$ mice had reduced body weight at that time point (Fig. 3E,F). No differences in estrous cycle length were noticed between $\mathrm{GHRH}^{\Delta \mathrm{ER} \alpha}$ and control littermates (Fig. $3 G)$. No alterations in feedback actions of estrogens on circulating LH levels were observed in OVX or in $\mathrm{OVX}+\mathrm{E}_{2}$ $\mathrm{GHRH}^{\Delta \mathrm{ER} \alpha}$ females (Fig. $3 H$ ).

\section{Mice with deletion of AR in GHRH} cells have normal growth but females show delayed pubertal completion Using the GHRH ${ }^{\text {Cre }}$-eGFP mice, we found expression of $\mathrm{AR}$ in $\sim 12 \%$ of $\mathrm{eGFP}^{+}$neurons of the POA, 30\% of the $\mathrm{ZIm}$, and $23 \%$ of the ARH in adult male mice (Fig. $4 A a, B b$ ), indicating a direct modulation of a subpopulation of GHRH cells by androgens (Zeitler et al., 1990). In adult females, virtually no AR/eGFP colocalization was observed in the POA, and low coexpression was observed in the ZIm (10.32 $\pm 4.54 \%$ of $\mathrm{eGFP}^{+}$neurons) and $\mathrm{ARH}(3.15 \pm$ $1.01 \%)$.

Deletion of AR specifically in GHRH cells was validated using double immunofluorescence for AR and GHRH-eGFP ${ }^{+}$ cells (Fig. 4Cc). Minimal or virtually no colocalization was observed in each of the brain sites previously described.

Phenotypically, the absence of AR in GHRH cells did not induce alterations in body weight or body length in males or females (Fig. $4 D, E$ ). The timing of puberty onset was not altered in GHRH ${ }^{\Delta A R}$ males and females (Fig. 4F,G). However, the timing for puberty completion was delayed in GHRH ${ }^{\Delta \mathrm{AR}}$ female mice (Fig. $4 H)$. The estrous cyclicity was similar in $\mathrm{GHRH}^{\Delta \mathrm{AR}}$ mice compared with controls (Fig. 4I). Collectively, our data demonstrate that direct androgen signaling in GHRH cells is required for typical pubertal completion in females but is not necessary for growth in mice.

\section{Number of ARH GHRH ${ }^{\text {Cre }}$-eGFP and Kiss $1^{\mathrm{Cre}}$-eGFP neurons increases during pubertal transition}

ARH Ghrh gene expression is increased by gonadal steroids (Zeitler et al., 1990; Fodor et al., 2001; Kamegai et al., 2001; Shimizu et al., 2005). Using the reporter mice, we evaluated whether gonadal steroid-induced change in ARH Ghrh expression is associated with an increase in the number of $\mathrm{GHRH}^{\mathrm{Cre}}$ eGFP neurons. GHRH $\mathrm{Cre}^{\mathrm{C}+}$-eGFP adult (P60) male and female 
mice showed an increase in the number of ARH GHRH-eGFP ${ }^{+}$cells compared with prepubertal (P21) mice (Fig. 5A-E). These findings indicate that an increase in the number of ARH neurons expressing GHRH occurs during pubertal transition.

Because the hypophysiotropic GHRH neurons are mostly located in the ARH and both mutant mice showed delay in pubertal completion, we evaluated the potential crosstalk between GHRH and Kiss1 neurons. ARH Kiss1 expression increases during pubertal transition (Takumi et al., 2011; Semaan and Kauffman, 2015). Using a transgenic mouse line, we initially evaluated whether the number of ARH Kiss $1^{\text {Cre }}$ eGFP cells change in males and females during pubertal development. Similar to $\mathrm{GHRH}^{\mathrm{Cre} /+}$-eGFP adult mice, we found that the number of $\mathrm{ARH}$ Kiss ${ }^{\mathrm{Cre}}$-eGFP ${ }^{+}$ cells in males and females is higher in adult mice (Fig. 5F-J). Specifically, adult diestrus Kiss $1^{\text {Cre }}$ mice showed an increase in the number of $\mathrm{ARH} \mathrm{eGFP}^{+}$cells compared with prepubertal ( $n=5 /$ group; $p=0.0004$ ) females. Likewise, compared with prepubertal males, the number of ARH Kiss $1^{\text {Cre }}$ eGFP neurons was elevated in adult $(n=4$ or 5/group; $p=0.017$ ) mice (Fig. 5J). Notably, adult females showed a higher number of ARH Kiss ${ }^{\text {Cre }}$-eGFP ${ }^{+}$cells compared with adult males $(p=0.03)$. Our data indicate that, as observed for transcript levels, pubertal transition is associated with an increased number of Kiss $1^{\mathrm{Cre}}-\mathrm{eGFP}^{+}$cells.

\section{GHRH $^{\text {tdTom }}$ neurons of adult females coexpress Kiss $1^{\text {hrGFP }}$}

Since gonadal steroids alter ARH Ghrh and Kiss 1 expression and ablation of gonadal steroid signaling in GHRH cells alters sexual maturation, we investigated the interconnection between both neuropeptide systems at the central level during development. A dual-reporter mouse model expressing $\mathrm{GHRH}^{\mathrm{Cre} /+}$-tdTomato and Kiss1-hrGFP (GHRH ${ }^{\text {tdTom }}:$ Kiss $1^{\text {hrGFP }}$ ) was generated to determine the potential and degree of colocalization between both neuronal populations in the ARH of males and females.

In adult females, we found that $\sim 32 \%$ of ARH GHRH ${ }^{\text {tdTom }}$ neurons coexpress Kiss $1^{\text {hrGFP }}$ and $\sim 47 \%$ of ARH Kiss $1^{\text {hrGFP }}$ neurons coexpress GHRH ${ }^{\text {tdTom }}$ (Fig. 6A-E). In contrast, virtually no coexpression of both reporter proteins was identified in AVPV neurons of adult GHRH ${ }^{\text {tdTom }}:$ Kiss $1^{\text {hrGFP }}$ mice. Reduced colabeling (2\%-3\%) was detected in prepubertal (P21) female mice (Fig. 6D,E). In males, ARH GHRH ${ }^{\text {tdTom }}$ cells showed minimal colocalization with Kiss $1^{\text {hrGFP }}$ neurons at prepubertal $(<1 \%)$ and adult $(3.04 \pm 0.99 \%)$ ages (Fig. $6 F-H)$.

Lack of colocalization of Ghrh and Kiss1 expression suggests a shift in neuropeptide production of adult female ARH neurons

In Kiss $1^{\text {hrGFP }}$ mice, the expression of the reporter gene is driven by endogenous Kiss1 expression and virtually all ARH Kiss1 ${ }^{\text {hrGFP }}$ neurons coexpress Kiss 1 mRNA in both intact and OVX mice (Cravo et al., 2011). In GHRH ${ }^{\text {tdTom }}$ mice, however, the expression of the reporter gene following Cre recombination is driven by a ubiquitous promoter (R26) and labels cells that expressed Ghrh during development. Thus, we assessed whether the GHRH ${ }^{\text {tdTom }}$ neurons in adult mice coexpress Ghrh mRNA. We found that, in prepubertal (P21) and peripubertal (P28-P36) mice, $\sim 90 \%$ of ARH neurons coexpress both reporter gene and mRNA, whereas in adult female only $\sim 50 \%$ of GHRH ${ }^{\text {tdTom }}$ neurons coexpress Ghrh mRNA (Fig. 7A-G). This is in agreement with the increased expression of Ghrh induced by gonadal steroids (Zeitler et al., 1990; Fodor et al., 2001; Kamegai et al., 2001; Shimizu et al., 2005) and the increased number of neurons expressing GHRH reporter gene shown in Figure 5A-E.

We then further evaluated whether Kiss 1 and Ghrh transcripts are colocalized in adult female mice. Females were evaluated in diestrus and after OVX to optimize Kiss1 expression (Smith et al., 2005). Very few or virtually no coexpression of both genes was observed in diestrus or in OVX mice (Fig. 7H,I). This finding indicates that, once pubertal completion is attained, a subset 

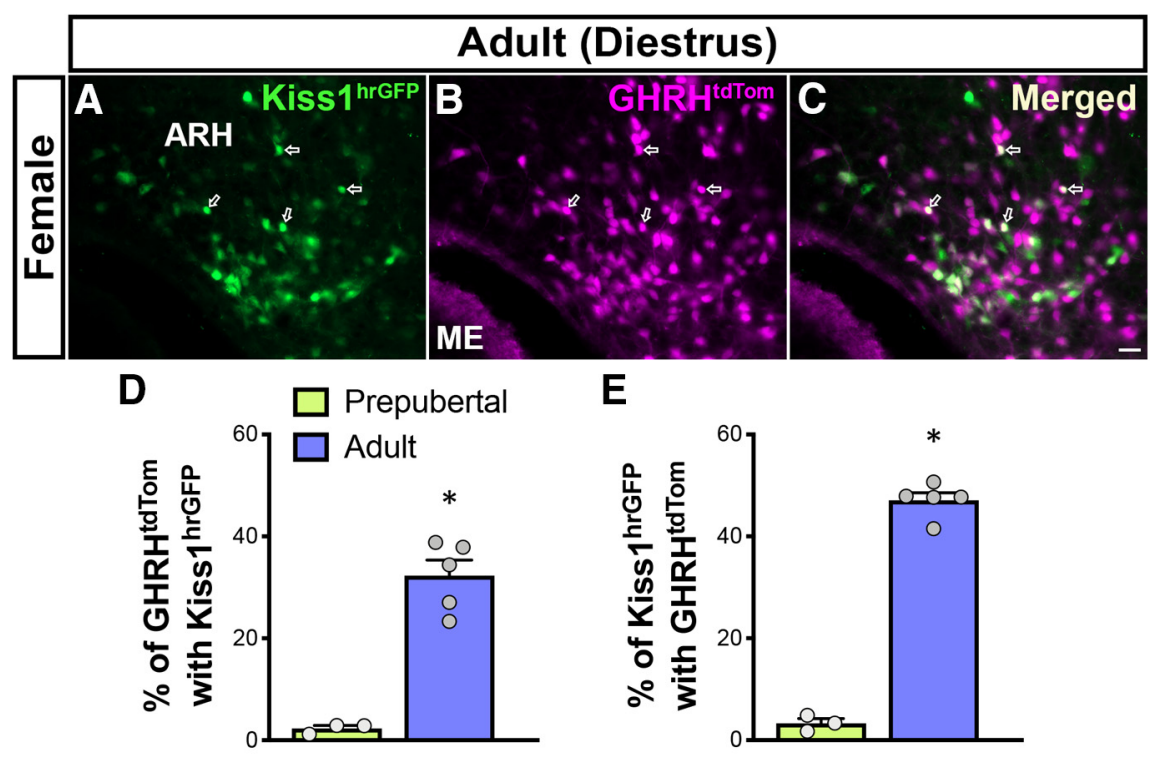

E
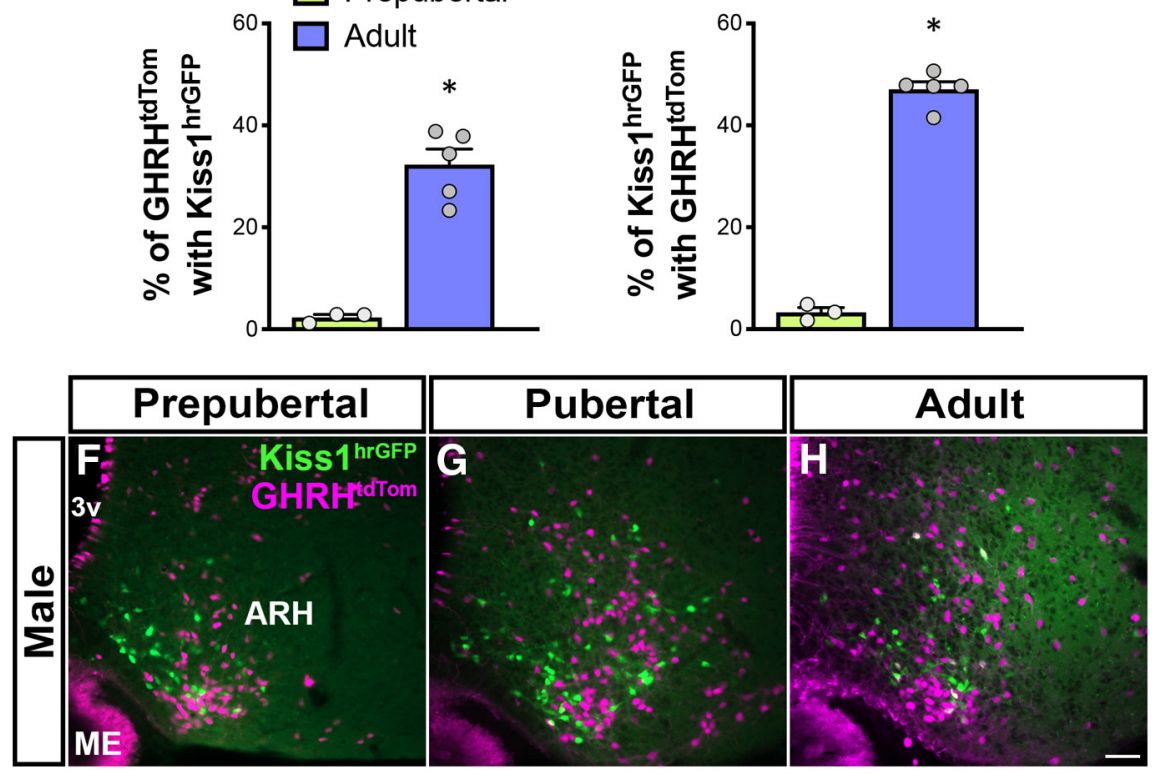

Figure 6. A subset of ARH GHRH ${ }^{\text {tdTom }}$ neurons coexpress Kiss $1^{\text {hrGFP }}$ in adult females. $\boldsymbol{A}, \boldsymbol{B}$, Fluorescent micrographs showing the distribution of ARH Kiss1 ${ }^{\text {hrGFP }}$ (green) and GHRH ${ }^{\text {tdTom }}$ (magenta) neurons in the ARH in adult (P56) female. $\boldsymbol{C}$, Merge of $\boldsymbol{A}$ and $\boldsymbol{B}$ shows that a subpopulation of GHRH ${ }^{\text {tdTom }}$ neurons coexpress Kiss $1^{\text {hrGFP }}$ (arrows). D, Quantification of ARH GHRH ${ }^{\text {tdTom }}$ neurons that coexpress Kiss $1^{\text {hrGFP }}$ in prepubertal (P21: $\left.2.31 \pm 1.38 \%\right)$ and adult (P60: $\left.32.3 \pm 3.05 \%\right)$ females ( $n=3-5 /$ group). $\boldsymbol{E}$, Quantification of ARH Kiss1 ${ }^{\text {hrGFP }}$ neurons that coexpress GHRH ${ }^{\text {tdTom }}$ in prepubertal $(3.32 \pm 2.23 \%)$ and adult $(47.08 \pm$ $1.51 \%$ ) females. $\boldsymbol{F}-\boldsymbol{H}$, Representative dual-fluorescent micrographs showing minimal colocalization of GHRH ${ }^{\text {tdTom }}$ and Kiss ${ }^{\text {hrGFP }}$ at three different stages of the male postnatal development: prepubertal $(P 21, n=4)$, pubertal $(P 36, n=3)$, and adult (P84, $n=5$ ). Each point represents 1 individual mouse. $* p<0.05$ (nonparametric two-tailed $U$ test). ME, Median eminence; $3 \mathrm{~V}$, third ventricle. Scale bars: $\boldsymbol{A}-\boldsymbol{C}, 20 \mu \mathrm{m} ; \boldsymbol{F}-\boldsymbol{H}, 50 \mu \mathrm{m}$.

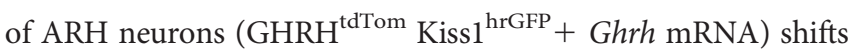
chemical phenotype from Ghrh to Kiss1 expression. Because virtually all ARH Kiss1 neurons coexpress ER $\alpha$ at different stages of development (Smith et al., 2005; Cravo et al., 2011; Kumar et al., 2015; Greenwald-Yarnell et al., 2016), the subpopulation of $\mathrm{GHRH}^{\text {tdTom }}$ neurons directly responsive to estrogens $(\sim 45 \%)$ likely overlaps with the dual-phenotype GHRH/Kiss1 neurons.

We next assessed whether lack of $\mathrm{ER} \alpha$ in GHRH neurons changes the pattern of colocalization of both reporter proteins in

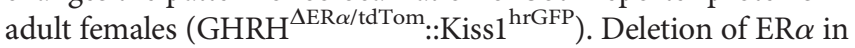
GHRH neurons induced no changes in the percentage of ARH $\mathrm{GHRH}^{\text {tdTom }}$ neurons that coexpress Kiss $1^{\text {hrGFP }}(34.74 \pm 0.84 \%$, $n=4)$ in adult (P56) females. However, a small but significant reduction in the percentage of $\mathrm{ARH}$ Kiss $1^{\text {hrGFP }}$ neurons that coexpress GHRH ${ }^{\text {tdTom }}(29.38 \pm 2.40 \% ; p=0.016$, by two-tailed $U$ test) was observed.

\section{Discussion}

In this study, we show that subpopulations of hypothalamic GHRH neurons express ER $\alpha$ or AR. Although the number of ARH GHRH neurons coexpressing AR is low, higher colocalization was observed in the ZIm. Selective deletion of ER $\alpha$ in GHRH cells disrupts growth in both sexes and pubertal progression in females, and lack of AR in GHRH cells causes only a delay in female pubertal completion. Using a mouse model of dual-reporter genes and developmental analysis of Ghrh and Kiss1 expression, we found that a subset of GHRH/ER $\alpha$ neurons appear to shift phenotype to become Kiss1/ER $\alpha$ neurons in adult females.

Gonadal steroid actions in the regulation of endocrine function are attained by targeting distinct levels of the neuroendocrine axes. Estrogens and androgens (before or after aromatization) have a well-defined effect in the growth plate to regulate longitudinal growth, and in the gonads to control fertility. However, during pubertal maturation, our findings demonstrate that the orchestrated actions of both neuroendocrine axes are mainly controlled by direct steroid actions in hypothalamic neurons (Howard and Dunkel, 2019).

Correlational observations have highlighted the crucial role of estrogens in the activation of the $\mathrm{GH}$ axis during pubertal growth spurt. For example, independent studies demonstrated that $\mathrm{ER} \alpha$ is expressed in a subset of GHRH neurons, and that estrogen administration increases Ghrh expression and activates the growth axis (Chowen et al., 1996; Hassan et al., 2001; Shimizu et al., 2005). The number of GHRH-eGFP ${ }^{+}$ neurons increases and their biophysical properties change during pubertal transition. Both changes are not observed if mice are gonadectomized before puberty (Gouty-Colomer et al., 2010; McArthur et al., 2011). The role of estrogens in the regulation of bone homeostasis and in the fusion of the growth plate is also well defined (Ohlsson et al., 2012). Through ER $\alpha$ signaling, estrogens stimulate the somatotropic axis increasing circulating levels of GH and IGF-1 that directly act on skeletal growth and epiphyseal fusion (Wu et al., 2015). Whereas a considerable body of evidence had been collected, whether direct estrogen signaling via $\mathrm{ER} \alpha$ in GHRH neurons is necessary for pubertal growth spurt had not been demonstrated. In this regard, our findings build on the current knowledge as they show that estrogens act directly at the hypothalamic component of the somatotropic axis. Deletion of $\mathrm{ER} \alpha$ in GHRH neurons restrains Ghrh expression and IGF-1 production, inducing a delay in epiphyseal fusion and reduced body length. The latter may seem puzzling as delayed epiphyseal fusion is usually associated with increased body length in humans (Smith et al., 1994). However, after considering species differences, it is important to bear in mind that the effects of estrogens on linear growth are rather broad and complex. Mice with global deletion of aromatase (ArKO) or specific deletion of $\mathrm{ER} \alpha$ in somatotrophs ( $\mathrm{sER} \alpha$-KO mice) displayed reduced basal pituitary GH mRNA levels (Avtanski et al., 2014). Estradiol replacement in ArKO mice 
directly increases somatotrope $G h$ and Ghrhr expression (Yan et al., 2004). ERs are expressed in all zones of the growth plate and appear to have opposite actions on bone physiology. The current model predicts that low estradiol increases $\mathrm{GH}$ and chondrocyte proliferation, and high estradiol decreases GH-induced IGF-1 release and chondrocyte proliferation, accelerating growth plate fusion (Mauras et al., 1989; Weissberger et al., 1991). The delay in pubertal completion observed in $\mathrm{GHRH}^{\Delta \mathrm{ER} \alpha}$ female mice is in line with this model. Puberty onset is not affected, but increased estradiol is unable to modulate the growth axis. Low circulating IGF-1 decreases the rate of chondrocyte proliferation and hypertrophy, and the further stimulation of the gonadotropic axis, delaying pubertal completion and epiphyseal fusion. Of note, these pubertal deficits are similar to those described in self-limited delayed puberty (also known as constitutional delay in growth and puberty), the most common cause of delayed puberty associated with short stature in adolescents (Howard and Dunkel, 2019).

The role of androgens in GHRH neurons was not as clear. Studies have proposed that androgen modulation of the somatotropic axis is attained via AR in somatostatin neurons or following aromatization, via actions in ERs (Zeitler et al., 1990; Herbison, 1995). The lack of growth phenotype observed in $\mathrm{GHRH}^{\Delta \mathrm{AR}}$ mice is in agreement with this model and demonstrates that androgen signaling in GHRH neurons is not required for growth. However, the delayed sexual maturation in female $\mathrm{GHRH}^{\triangle \mathrm{AR}}$ mice indicates that direct androgen action in GHRH cells is required for typical pubertal progression. It is unlikely, though, that this outcome is caused by changes in hypophysiotropic ARH GHRH neurons because of the low AR colocalization $(\sim 3 \%)$ in females. The GHRH/AR neuronal population located in the ZIm is a potential candidate in this regard. A subset of ZIm GHRH neurons coexpress $\mathrm{TH}$, and $\mathrm{TH}$ expression in ZIm is modulated by gonadal steroids. Bilateral lesions of the ZIm disrupt LH preovulatory surge (Sanghera et al., 1991a,b). Thus, together with the current knowledge, our findings indicate that the pubertal delay observed in $\mathrm{GHRH}^{\triangle \mathrm{AR}}$ female mice is a result of altered ZIm neuronal circuitry or activity in the absence of androgen signaling. Additional studies are necessary to test this model.

In an attempt to gain insights into the mechanisms associated with GHRH role in typical pubertal transition, we evaluated the potential interaction with an essential neuropeptidergic system for sexual maturation in humans and rodents. Kisspeptins, encoded by the Kiss1 gene, are key mediators of the estrogen feedback mechanism for the control of pubertal timing and fertility (Garcia-Galiano et al., 2012; Pinilla et al., 2012). Virtually
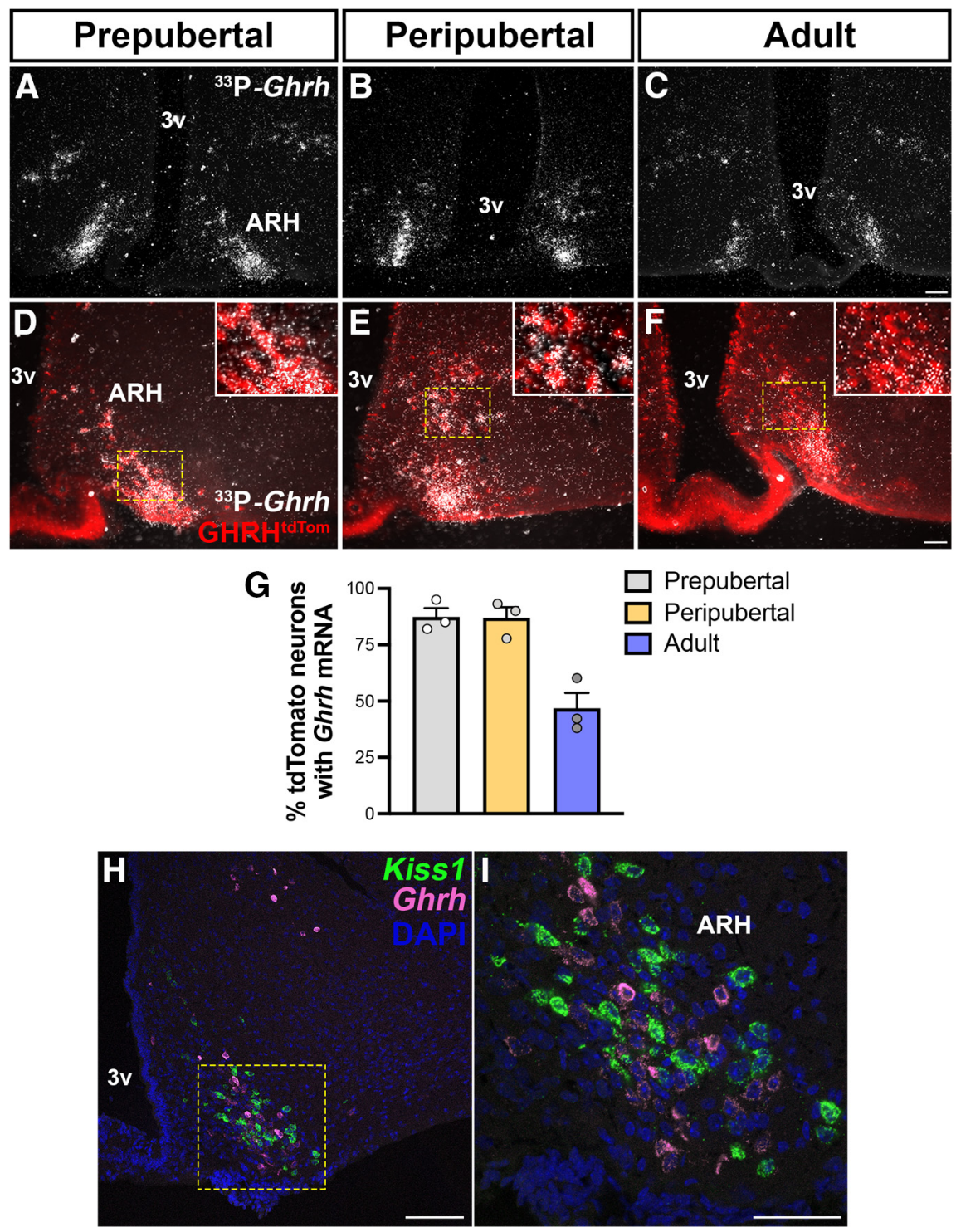

Figure 7. Changes in ARH Ghrh mRNA expression during development and localization with Kiss1 neurons. A-C, Representative darkfield micrographs showing Ghrh mRNA (hybridization signal) in the ARH of prepubertal, peripubertal, and rons in prepubertal, peripubertal, and adult females. Insets, Higher-magnification micrographs of the selected area. $\boldsymbol{G}$ Quantification of ARH Ghrh mRNA coexpression with GHRH ${ }^{\text {tdTom }}$ neurons during development. $\boldsymbol{H}, \boldsymbol{I}$, Representative confocal phase. DMH, Dorsomedial nucleus of the hypothalamus; 3v, third ventricle. Each point represents 1 individual mouse. Scale bars: $A-C, H, 100 \mu \mathrm{m} ; \boldsymbol{D}-\boldsymbol{F}, \boldsymbol{I}, 50 \mu \mathrm{m}$.

all ARH Kiss1 neurons express ER $\alpha$ at different stages of development (Smith et al., 2005; Cravo et al., 2011; Kumar et al., 2015; Greenwald-Yarnell et al., 2016). In adult female, but not male, mice, about half of Kiss $1^{\text {hrGFP }}$ neurons coexpress the GHRH ${ }^{\text {tdTom }}$. Because prepubertal mice show very low colocalization of both reporter genes and an increase in the number of $\mathrm{Kiss} 1^{\mathrm{Cre}}$ - or $\mathrm{GHRH}^{\mathrm{Cre}}$-eGFP cells was observed during pubertal transition, it is likely that the colocalization is a result of estrogen's action to increase the expression of both neuropeptides in overlapping neurons.

Deletion of ER $\alpha$ in Kiss1 or Tac2 (encoding for neurokinin B) cells (both colocalized in ARH, also known as KNDy neurons) advances puberty onset but disrupts pubertal completion (Mayer et al., 2010; Greenwald-Yarnell et al., 2016). Our mouse model with deletion of $\operatorname{ER} \alpha$ in a subset of Kiss1 neurons is consistent 
with these findings as it shows some aspects, albeit mild and partial, of the reproductive phenotype. Puberty onset is not altered in $\mathrm{GHRH}^{\mathrm{AER} \alpha}$ female mice, but completion is delayed.

The decrease in Ghrh expression is consistent with the progressive decline of $\mathrm{GH}$ secretion after pubertal completion (Wennink et al., 1991). Because gonadal steroids synthesis continues and Ghrh and Kiss 1 coexpression is negligible, we predict that a switch in the pattern of GHRH-Kiss1 expression and secretion is established during pubertal transition. In support of this concept are the studies showing that kisspeptins restrain GH release independent of direct GH feedback actions (Whitlock et al., 2010; Smith et al., 2018; Bohlen et al., 2019; Silveira et al., 2019). Thus, the increase of kisspeptin in detriment of GHRH release would be expected to decrease GH secretion and potentially stimulate the gonadotropic axis. The decrease in colocalization of GHRH ${ }^{\text {tdTom }}$ and Kiss $1^{\text {hrGFP }}$ in mice lacking ER $\alpha$ in GHRH neurons may explain in part the delay in female pubertal completion. Additional studies will be necessary to assess the direct role of estradiol on this phenotypic shift. Of note, phenotypic changes are observed in other hypothalamic neuronal populations during embryonic and postnatal development (e.g., $\mathrm{POMC} / \mathrm{NPY} /$ Kiss1 in the ARH), and in distinct physiological states (e.g., vGAT/vGLUT2 during rat estrous cycle in the preoptic area) (Ottem et al., 2004; Nilsson et al., 2005; Padilla et al., 2010; Sanz et al., 2015).

The lack of GHRH/Kiss1 colocalization in male mice is also remarkable. It unravels a key feature in the sex differences in the pattern of GH release and in the gonadal steroids control of growth and puberty (Frantz and Rabkin, 1965; Wennink et al., 1991; Steyn et al., 2016).

\section{References}

Avtanski D, Novaira HJ, Wu S, Romero CJ, Kineman R, Luque RM, Wondisford F, Radovick S (2014) Both estrogen receptor alpha and beta stimulate pituitary GH gene expression. Mol Endocrinol 28:40-52.

Bohlen TM, Zampieri TT, Furigo IC, Teixeira PD, List EO, Kopchick J, Donato J Jr, Frazao R (2019) Central growth hormone signaling is not required for the timing of puberty. J Endocrinol 243:161-173.

Bouyer K, Loudes C, Robinson IC, Epelbaum J, Faivre-Bauman A (2007) Multiple co-localizations in arcuate GHRH-eGFP neurons in the mouse hypothalamus. J Chem Neuroanat 33:1-8.

Brock O, De Mees C, Bakker J (2015) Hypothalamic expression of oestrogen receptor alpha and androgen receptor is sex-, age- and region-dependent in mice. J Neuroendocrinol 27:264-276.

Caron E, Ciofi P, Prevot V, Bouret SG (2012) Alteration in neonatal nutrition causes perturbations in hypothalamic neural circuits controlling reproductive function. J Neurosci 32:11486-11494.

Chowen JA, García-Segura LM, González-Parra S, Argente J (1996) Sex steroid effects on the development and functioning of the growth hormone axis. Cell Mol Neurobiol 16:297-310.

Cravo RM, Margatho LO, Osborne-Lawrence S, Donato J Jr, Atkin S, Bookout AL, Rovinsky S, Frazao R, Lee CE, Gautron L, Zigman JM, Elias CF (2011) Characterization of Kiss1 neurons using transgenic mouse models. Neuroscience 173:37-56.

Cravo RM, Frazao R, Perello M, Osborne-Lawrence S, Williams KW, Zigman JM, Vianna C, Elias CF (2013) Leptin signaling in Kiss1 neurons arises after pubertal development. PLoS One 8:e58698.

de Boer JA, Schoemaker J, van der Veen EA (1997) Impaired reproductive function in women treated for growth hormone deficiency during childhood. Clin Endocrinol (Oxf) 46:681-689.

de Boer JA, van der Meer M, van der Veen EA, Schoemaker J (1999) Growth hormone (GH) substitution in hypogonadotropic, GH-deficient women decreases the follicle-stimulating hormone threshold for monofollicular growth. J Clin Endocrinol Metab 84:590-595.

De Gendt K, Swinnen JV, Saunders PT, Schoonjans L, Dewerchin M, Devos A, Tan K, Atanassova N, Claessens F, Lecureuil C, Heyns W, Carmeliet P, Guillou F, Sharpe RM, Verhoeven G (2004) A Sertoli cell-selective knockout of the androgen receptor causes spermatogenic arrest in meiosis. Proc Natl Acad Sci USA 101:1327-1332.

Feng Y, Manka D, Wagner KU, Khan SA (2007) Estrogen receptor-alpha expression in the mammary epithelium is required for ductal and alveolar morphogenesis in mice. Proc Natl Acad Sci USA 104:14718-14723.

Fodor M, Oudejans CB, Delemarre-van de Waal HA (2001) Absence of androgen receptor in the growth hormone releasing hormone-containing neurones in the rat mediobasal hypothalamus. J Neuroendocrinol 13:724-727.

Frantz AG, Rabkin MT (1965) Effects of estrogen and sex difference on secretion of human growth hormone. J Clin Endocrinol Metab 25:1470-1480.

Frazao R, Cravo RM, Donato J Jr, Ratra DV, Clegg DJ, Elmquist JK, Zigman JM, Williams KW, Elias CF (2013) Shift in Kiss1 cell activity requires estrogen receptor alpha. J Neurosci 33:2807-2820.

Garcia-Galiano D, Pinilla L, Tena-Sempere M (2012) Sex steroids and the control of the Kiss1 system: developmental roles and major regulatory actions. J Neuroendocrinol 24:22-33.

Garcia-Galiano D, Borges BC, Donato J Jr, Allen SJ, Bellefontaine N, Wang M, Zhao JJ, Kozloff KM, Hill JW, Elias CF (2017) PI3K $\alpha$ inactivation in leptin receptor cells increases leptin sensitivity but disrupts growth and reproduction. JCI Insight 2:e96728.

Giampietro A, Milardi D, Bianchi A, Fusco A, Cimino V, Valle D, Marana R, Pontecorvi A, De Marinis L (2009) The effect of treatment with growth hormone on fertility outcome in eugonadal women with growth hormone deficiency: report of four cases and review of the literature. Fertil Steril 91:930-937.911.

Gouty-Colomer LA, Méry PF, Storme E, Gavois E, Robinson IC, Guérineau NC, Mollard P, Desarménien MG (2010) Specific involvement of gonadal hormones in the functional maturation of growth hormone releasing hormone (GHRH) neurons. Endocrinology 151:5762-5774.

Greenberg GD, Howerton CL, Trainor BC (2014) Fighting in the home cage: agonistic encounters and effects on neurobiological markers within the social decision-making network of house mice (Mus musculus). Neurosci Lett 566:151-155.

Greenwald-Yarnell ML, Marsh C, Allison MB, Patterson CM, Kasper C, MacKenzie A, Cravo R, Elias CF, Moenter SM, Myers MG Jr (2016) ERalpha in Tac2 neurons regulates puberty onset in female mice. Endocrinology 157:1555-1565.

Hassan HA, Enright WJ, Tucker HA, Merkel RA (2001) Estrogen and androgen elicit growth hormone release via dissimilar patterns of hypothalamic neuropeptide secretion. Steroids 66:71-80.

Herbison AE (1995) Sexually dimorphic expression of androgen receptor immunoreactivity by somatostatin neurones in rat hypothalamic periventricular nucleus and bed nucleus of the stria terminalis. J Neuroendocrinol 7:543-553

Hokfelt T, Johansson O, Fuxe K, Goldstein M, Park D (1976) Immunohistochemical studies on the localization and distribution of monoamine neuron systems in the rat brain: I. Tyrosine hydroxylase in the mes- and diencephalon. Med Biol 54:427-453.

Howard SR, Dunkel L (2019) Delayed puberty-phenotypic diversity, molecular genetic mechanisms, and recent discoveries. Endocr Rev 40:12851317.

Kamegai J, Tamura H, Shimizu T, Ishii S, Sugihara H, Wakabayashi I (2001) Estrogen receptor (ER)alpha, but not ERbeta, gene is expressed in growth hormone-releasing hormone neurons of the male rat hypothalamus. Endocrinology 142:538-543.

Karpati AM, Rubin CH, Kieszak SM, Marcus M, Troiano RP (2002) Stature and pubertal stage assessment in American boys: the 1988-1994 Third National Health and Nutrition Examination Survey. J Adolesc Health 30:205-212.

Kelly A, Winer KK, Kalkwarf H, Oberfield SE, Lappe J, Gilsanz V, Zemel BS (2014) Age-based reference ranges for annual height velocity in US children. J Clin Endocrinol Metab 99:2104-2112.

Krashes MJ, Shah BP, Madara JC, Olson DP, Strochlic DE, Garfield AS, Vong L, Pei H, Watabe-Uchida M, Uchida N, Liberles SD, Lowell BB (2014) An excitatory paraventricular nucleus to AgRP neuron circuit that drives hunger. Nature 507:238-242.

Kumar D, Candlish M, Periasamy V, Avcu N, Mayer C, Boehm U (2015) Specialized subpopulations of kisspeptin neurons communicate with GnRH neurons in female mice. Endocrinology 156:32-38. 
Low KL, Ma C, Soma KK (2017) Tyramide signal amplification permits immunohistochemical analyses of androgen receptors in the rat prefrontal cortex. J Histochem Cytochem 65:295-308.

MacKenzie FJ, Hunter AJ, Daly C, Wilson CA (1984) Evidence that the dopaminergic incerto-hypothalamic tract has a stimulatory effect on ovulation and gonadotrophin release. Neuroendocrinology 39:289-295.

Madisen L, Zwingman TA, Sunkin SM, Oh SW, Zariwala HA, Gu H, Ng LL, Palmiter RD, Hawrylycz MJ, Jones AR, Lein ES, Zeng H (2010) A robust and high-throughput Cre reporting and characterization system for the whole mouse brain. Nat Neurosci 13:133-140.

Mangiavini L, Merceron C, Schipani E (2016) Analysis of mouse growth plate development. Curr Protoc Mouse Biol 6:67-130.

Mauras N, Rogol AD, Veldhuis JD (1989) Specific, time-dependent actions of low-dose ethinyl estradiol administration on the episodic release of growth hormone, follicle-stimulating hormone, and luteinizing hormone in prepubertal girls with Turner's syndrome. J Clin Endocrinol Metab 69:1053-1058.

Mayer C, Acosta-Martinez M, Dubois SL, Wolfe A, Radovick S, Boehm U, Levine JE (2010) Timing and completion of puberty in female mice depend on estrogen receptor alpha-signaling in kisspeptin neurons. Proc Natl Acad Sci USA 107:22693-22698.

McArthur S, Robinson IC, Gillies GE (2011) Novel ontogenetic patterns of sexual differentiation in arcuate nucleus GHRH neurons revealed in GHRHenhanced green fluorescent protein transgenic mice. Endocrinology 152:607-617.

Meister B, Hokfelt T, Vale WW, Sawchenko PE, Swanson L, Goldstein M (1986) Coexistence of tyrosine hydroxylase and growth hormone-releasing factor in a subpopulation of tubero-infundibular neurons of the rat. Neuroendocrinology 42:237-247.

Merchenthaler I, Lane MV, Numan S, Dellovade TL (2004) Distribution of estrogen receptor alpha and beta in the mouse central nervous system: in vivo autoradiographic and immunocytochemical analyses. J Comp Neurol 473:270-291.

Nilsson I, Johansen JE, Schalling M, Hokfelt T, Fetissov SO (2005) Maturation of the hypothalamic arcuate agouti-related protein system during postnatal development in the mouse. Brain Res Dev Brain Res 155:147-154.

Ohlsson C, Engdahl C, Borjesson AE, Windahl SH, Studer E, Westberg L, Eriksson E, Koskela A, Tuukkanen J, Krust A, Chambon P, Carlsten H, Lagerquist MK (2012) Estrogen receptor-alpha expression in neuronal cells affects bone mass. Proc Natl Acad Sci USA 109:983-988.

Ottem EN, Godwin JG, Krishnan S, Petersen SL (2004) Dual-phenotype $\mathrm{GABA} /$ glutamate neurons in adult preoptic area: sexual dimorphism and function. J Neurosci 24:8097-8105.

Padilla SL, Carmody JS, Zeltser LM (2010) Pomc-expressing progenitors give rise to antagonistic neuronal populations in hypothalamic feeding circuits. Nat Med 16:403-405.

Palmert MR, Dunkel L (2012) Clinical practice: delayed puberty. N Engl J Med 366:443-453.

Pasqualini C, Bojda F, Gaudoux F, Guibert B, Leviel V, Teissier E, Rips R, Kerdelhue B (1988) Changes in tuberoinfundibular dopaminergic neuron activity during the rat estrous cycle in relation to the prolactin surge: alteration by a mammary carcinogen. Neuroendocrinology 48:320-327.

Phelps CJ, Romero MI, Hurley DL (2003) Growth hormone-releasing hormone-producing and dopaminergic neurones in the mouse arcuate nucleus are independently regulated populations. J Neuroendocrinol 15:280-288

Pinilla L, Aguilar E, Dieguez C, Millar RP, Tena-Sempere M (2012) Kisspeptins and reproduction: physiological roles and regulatory mechanisms. Physiol Rev 92:1235-1316.

Rosenfeld RG (2003) Insulin-like growth factors and the basis of growth. N Engl J Med 349:2184-2186.

Rupp AC, Allison MB, Jones JC, Patterson CM, Faber CL, Bozadjieva N, Heisler LK, Seeley RJ, Olson DP, Myers MG Jr (2018) Specific subpopulations of hypothalamic leptin receptor-expressing neurons mediate the effects of early developmental leptin receptor deletion on energy balance. Mol Metab 14:130-138.

Sanghera MK, Anselmo-Franci J, McCann SM (1991a) Effect of medial zona incerta lesions on the ovulatory surge of gonadotrophins and prolactin in the rat. Neuroendocrinology 54:433-438.
Sanghera MK, Grady S, Smith W, Woodward DJ, Porter JC (1991b) Incertohypothalamic A13 dopamine neurons: effect of gonadal steroids on tyrosine hydroxylase. Neuroendocrinology 53:268-275.

Sanz E, Quintana A, Deem JD, Steiner RA, Palmiter RD, McKnight GS (2015) Fertility-regulating Kiss1 neurons arise from hypothalamic POMC-expressing progenitors. J Neurosci 35:5549-5556.

Semaan SJ, Kauffman AS (2015) Daily successive changes in reproductive gene expression and neuronal activation in the brains of pubertal female mice. Mol Cell Endocrinol 401:84-97.

Shimizu T, Kamegai J, Tamura H, Ishii S, Sugihara H, Oikawa S (2005) The estrogen receptor (ER) alpha, but not ER beta, gene is expressed in hypothalamic growth hormone-releasing hormone neurons of the adult female rat. Neurosci Res 52:121-125.

Silveira MA, Zampieri TT, Furigo IC, Abdulkader F, Donato J Jr, Frazao R (2019) Acute effects of somatomammotropin hormones on neuronal components of the hypothalamic-pituitary-gonadal axis. Brain Res 1714:210-217.

Sisk CL, Foster DL (2004) The neural basis of puberty and adolescence. Nat Neurosci 7:1040-1047.

Smith EP, Boyd J, Frank GR, Takahashi H, Cohen RM, Specker B, Williams TC, Lubahn DB, Korach KS (1994) Estrogen resistance caused by a mutation in the estrogen-receptor gene in a man. N Engl J Med 331:10561061.

Smith JT, Cunningham MJ, Rissman EF, Clifton DK, Steiner RA (2005) Regulation of Kiss1 gene expression in the brain of the female mouse. Endocrinology 146:3686-3692.

Smith JT, Roseweir A, Millar M, Clarke IJ, Millar RP (2018) Stimulation of growth hormone by kisspeptin antagonists in ewes. J Endocrinol 237:165-173.

Smuel K, Kauli R, Lilos P, Laron Z (2015) Growth, development, puberty and adult height before and during treatment in children with congenital isolated growth hormone deficiency. Growth Horm IGF Res 25:182-188.

Steyn FJ, Wan Y, Clarkson J, Veldhuis JD, Herbison AE, Chen C (2013) Development of a methodology for and assessment of pulsatile luteinizing hormone secretion in juvenile and adult male mice. Endocrinology 154:4939-4945.

Steyn FJ, Tolle V, Chen C, Epelbaum J (2016) Neuroendocrine regulation of growth hormone secretion. Compr Physiol 6:687-735.

Suter KJ, Pohl CR, Wilson ME (2000) Circulating concentrations of nocturnal leptin, growth hormone, and insulin-like growth factor-I increase before the onset of puberty in agonadal male monkeys: potential signals for the initiation of puberty. J Clin Endocrinol Metab 85:808-814.

Takumi K, Iijima N, Ozawa H (2011) Developmental changes in the expression of kisspeptin mRNA in rat hypothalamus. J Mol Neurosci 43:138145.

Wasinski F, Pedroso JA, Dos Santos WO, Furigo IC, Garcia-Galiano D, Elias CF, List EO, Kopchick JJ, Szawka RE, Donato J Jr (2020) Tyrosine hydroxylase neurons regulate growth hormone secretion via short-loop negative feedback. J Neurosci 40:4309-4322.

Weissberger AJ, Ho KK, Lazarus L (1991) Contrasting effects of oral and transdermal routes of estrogen replacement therapy on 24-hour growth hormone $(\mathrm{GH})$ secretion, insulin-like growth factor I, and GH-binding protein in postmenopausal women. J Clin Endocrinol Metab 72:374-381.

Wennink JM, Delemarre-van de Waal HA, Schoemaker R, Blaauw G, van den Braken C, Schoemaker J (1991) Growth hormone secretion patterns in relation to $\mathrm{LH}$ and estradiol secretion throughout normal female puberty. Acta Endocrinol (Copenh) 124:129-135.

Whitlock BK, Daniel JA, Wilborn RR, Maxwell HS, Steele BP, Sartin JL (2010) Interaction of kisspeptin and the somatotropic axis. Neuroendocrinology 92:178-188.

Wu S, Yang W, De Luca F (2015) Insulin-like growth factor-independent effects of growth hormone on growth plate chondrogenesis and longitudinal bone growth. Endocrinology 156:2541-2551.

Yan M, Jones ME, Hernandez M, Liu D, Simpson ER, Chen C (2004) Functional modification of pituitary somatotropes in the aromatase knockout mouse and the effect of estrogen replacement. Endocrinology 145:604-612.

Zeitler P, Argente J, Chowen-Breed JA, Clifton DK, Steiner RA (1990) Growth hormone-releasing hormone messenger ribonucleic acid in the hypothalamus of the adult male rat is increased by testosterone. Endocrinology 127:1362-1368. 